Check for updates

Cite this: New J. Chem., 2022, 46,4534

Received 3rd January 2022

Accepted 14th February 2022

DOI: 10.1039/d2nj00026a

rsc.li/njc

\title{
Acylselenoureas, selenosemicarbazones and selenocarbamate esters: Versatile ligands in coordination chemistry
}

\author{
Anja Molter, Julia Kuchar (D) and Fabian Mohr (D)*
}

\begin{abstract}
This article reviews the syntheses, structures, reactions and applications of metal complexes with both transition- and main-group-metals containing selenium compounds including acylselenoureas, selenosemicarbazones and selenocarbamate esters as ligands. Literature up to November 2021 has been covered.
\end{abstract}

\section{Introduction}

There are a number of selenium compounds containing the $\mathrm{Y}-\mathrm{NHC}(\mathrm{Se})-\mathrm{Z}$ unit (Fig. 1). This moiety may in principle coordinate to a metal as either a neutral Se-donor or, upon deprotonation, as anionic Se- or $\mathrm{N}$-donor or as chelating [Se,N]-ligand. If $\mathrm{Y}=\operatorname{ArC}(\mathrm{O})$ and $\mathrm{Z}=\mathrm{NR}_{2}$ the compounds are known as acylselenoureas, when $\mathrm{Y}=\mathrm{R}_{2} \mathrm{C}=\mathrm{N}$ and $\mathrm{Z}=\mathrm{NR}_{2}$ they are selenosemicarbazones and when $\mathrm{Y}=\mathrm{Ar}$ and $\mathrm{Z}=\mathrm{OR}$ selenocarbamate esters (Fig. 1). As is evident, there is ample

Anorganische Chemie, Fakultät für Mathematik und Naturwissenschaften, Bergische Universität Wuppertal, 42119 Wuppertal, Germany.

E-mail: fmohr@uni-wuppertal.de opportunity to introduce structural diversity and additional functionality in these compounds.

The coordination chemistry of these three classes of selenium compounds (acylselenoureas, selenosemicarbazones and selenocarbamate esters) is subject of this article. Discussed are syntheses, structures, reactivity and applications of metal complexes with both transition metals and main group metals containing these selenium compounds as ligands. Although much of the work reviewed herein is older, in recent years new applications have been discovered, especially in the materials sciences and medicine, which have led to a renaissance in this area. In 2014 a review on the synthesis and biological applications of selenoureas was published, but focus here was the organic chemistry of this class of compounds. ${ }^{1}$ There also exists
Dr Anja Molter studied chemistry at the University of Braunschweig before joining the research group of professor Fabian Mohr at the University of Wuppertal for her PhD. Her research focused on metal complexes with various selenium compounds as ligands as well as the study of their biological properties. After completion of her PhD, Dr Molter became a chemistry and physics teacher at a high school in Solingen.

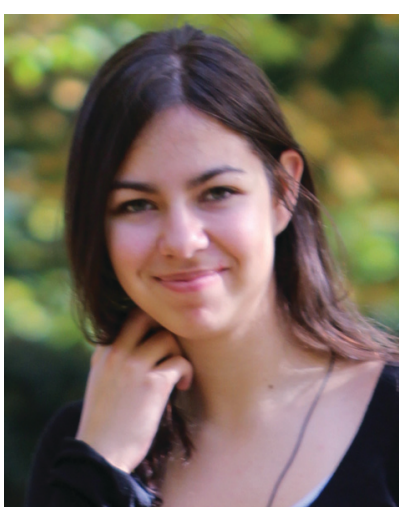

Julia Kuchar
Julia Kuchar completed her Bachelor's degree in chemistry in 2017 at the University of Wuppertal. After her Master's degree she commenced her PhD studies in 2019 at the same University in the research group of professor Fabian Mohr. During her undergraduate studies she worked on silver complexes with antimicrobial activity, as well as on the coordination chemistry of acylthioureas and acylselenoureas with coinage metals.

Currently she is focusing on selenium-containing heterocycles and their biological activity. Julia is also treasurer of the JungChemikerForum Wuppertal-Hagen, a regional section of the youth organisation of the German Chemical Society. 


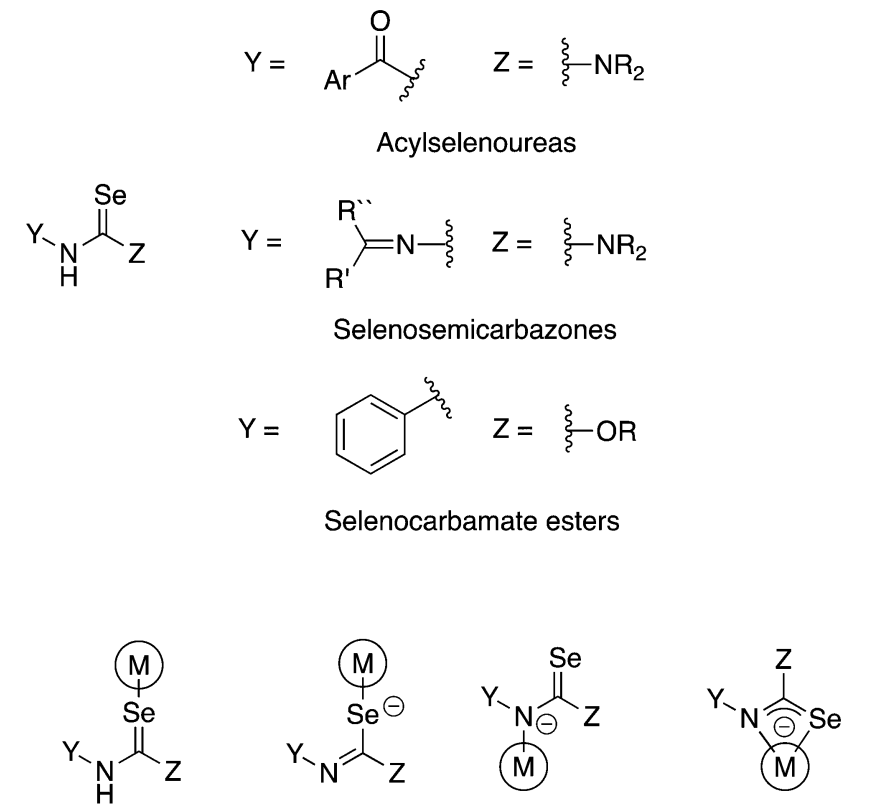

Fig. 1 Schematic illustration of selenium compounds containing the $-\mathrm{NHC}(\mathrm{Se})$ - unit (top) and their possible coordination modes (bottom).

a review on the coordination chemistry of acylselenoureas published in Spanish in $1983^{2}$ but, to the best of our knowledge, the coordination chemistry of selenosemicarbazones has to date not been reviewed. Given that the field has considerably advanced in the past years, we felt it was timely to provide an update and summary of both the historic, pioneering work and latest developments.

\section{Acylselenoureas}

Acylselenoureas of the type $\operatorname{ArC}(\mathrm{O}) \mathrm{NHC}(\mathrm{Se}) \mathrm{NR}_{2}$ were first reported by Douglass in $1937 .{ }^{3}$ These compounds can be prepared from the reaction of an acid chloride with $\mathrm{KSeCN}$ in acetone to form

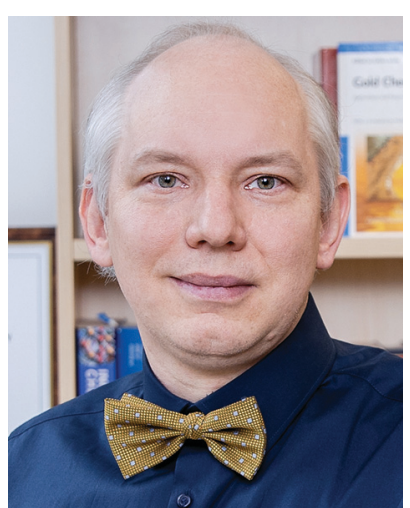

Fabian Mohr
Professor Mohr carried out both his undergraduate studies and his PhD in chemistry at RMIT University in Melbourne, Australia. After postdoctoral stays at the University of Western Ontario and the University of Maryland, he moved to the University of Zaragoza in Spain with a Spanish research scholarship. In 2006 Fabian joined the University of Wuppertal as junior professor and became professor of inorganic chemistry there in 2014. Fabian is editor of a book on gold chemistry and has published more than 130 scientific articles mostly on the chemistry of precious metals and chalcogen ligands, especially those containing selenium. intermediate acylisoselenocyanates $\operatorname{ArC}(\mathrm{O}) \mathrm{N}=\mathrm{C}=\mathrm{Se}$ (amongst other oligomeric compounds ${ }^{4}$ ) which are generally not isolated and immediately reacted with a primary or secondary amine to give the desired acylselenoureas (Scheme 1).

Although yields are extremely variable, this general procedure is still the method of choice for the synthesis of acylselenoureas. Subsequently in the 1960's and 1970's, the group of Bulka studied this reaction in some detail and (unsuccessfully) attempted to isolate the acylisoselenocyanates. ${ }^{5,6}$ The same procedure was later also used by Koketsu ${ }^{7}$ and Pazdera ${ }^{8}$ to prepare a variety of new selenourea derivatives. An alternative method using $\mathrm{CH}_{2} \mathrm{Cl}_{2}$ as solvent and polyethylene glycol 400 as a phase-transfer catalyst was reported by Zhang. ${ }^{9,10}$ Apart from the acylselenoureas derived from aromatic acid chlorides and anilines or dialkyl amines, there are also examples containing carbohydrate moieties (Fig. 2). These include the acylselenourea prepared from benzoyl chloride and $O$-acetylprotected glucosamine, as well as the acylselenourea obtained from the reaction of an $O$-acetyl-protected gluconyl isoselenocyanate with aniline. ${ }^{11,12}$

As will be shown below, the coordination chemistry of acylselenourea derivatives is so far restricted to those formed from aromatic acid chlorides and secondary amines. Table 1 lists these known acylselenoureas together with their yields and CCDC deposition codes for those compounds whose structures have been determined. The only metal-containing acylselenoureas derived from primary amines are the ferrocenyl-substituted derivatives $\mathrm{ArC}(\mathrm{O}) \mathrm{NHC}(\mathrm{Se}) \mathrm{NHC}_{6} \mathrm{H}_{4} \mathrm{Fc}$ which have been investigated in some detail by the group of Badshah. ${ }^{13-19}$

The first crystallographic study of two acylselenoureas is mentioned in a short note from 1963, in which only unit cell parameters and space groups are disclosed. ${ }^{31}$ The first full structure determination of an acylselenourea, that of PhC(O)NHC(Se)NHPh, was published by Hope in $1965,{ }^{32}$ since then a total of 28 crystal structures of acylselenoureas have been deposited with the CCDC. A common feature in the structures derived from primary amines is the formation of a six-membered ring containing the $\mathrm{NHC}(\mathrm{Se}) \mathrm{NHC}(\mathrm{O})$ unit, which is stabilised through an intramolecular hydrogen bond between the $\mathrm{N}-\mathrm{H}$ proton and the carbonyl oxygen atom (Fig. 3).

In the solid-state structures of acylselenoureas derived from secondary amines (Table 1), the intramolecular hydrogen bond can of course not be formed, thus the angle between the $\mathrm{CO}$ and CSe moieties varies from compound to compound.

It was the group of Beyer and Kirmse who first showed that $\mathrm{PhC}(\mathrm{O}) \mathrm{NHC}(\mathrm{Se}) \mathrm{NEt}_{2}$ reacts with $\mathrm{Ni}^{(\mathrm{II})}-\mathrm{Pd}^{(\mathrm{II})}-$ or $\mathrm{Co}^{(\mathrm{III})}$-acetate to give good yields of the square planar bis(chelate) complexes $\left[\mathrm{M}\left\{\mathrm{PhC}(\mathrm{O}) \mathrm{NC}(\mathrm{Se}) \mathrm{NEt}_{2}\right\}_{2}\right](\mathrm{M}=\mathrm{Ni}, \mathrm{Pd})$ or the octahedral tris(chelate) $\left[\mathrm{Co}\left\{\mathrm{PhC}(\mathrm{O}) \mathrm{NC}(\mathrm{Se}) \mathrm{NEt}_{2}\right\}_{3}\right]$, in which the deprotonated acylselenourea acts as an O,Se-chelate ligand (Scheme 2). ${ }^{33}$ The proposed structures of the bis(chelate) complexes, in which the acylselenoureato ligands are mutually cis, was initially deduced from single-crystal EPR spectroscopy of the $\mathrm{Cu}^{(\mathrm{II})}$ complex $\left[\mathrm{Cu}\left\{\mathrm{PhC}(\mathrm{O}) \mathrm{NC}(\mathrm{Se}) \mathrm{N}^{\mathrm{i}} \mathrm{Bu}_{2}\right\}_{2}\right] ;^{34}$ the first X-ray crystal structures of such metal bis(selenoureato) complexes appeared only in the 1990's (see below). 
<smiles></smiles>

Fig. 2 Acylselenoureas derived from carbohydrates.

Table 1 Known acylselenourea derivatives derived from aromatic acid chlorides and secondary amines

\begin{tabular}{|c|c|c|c|c|}
\hline $\mathrm{Ar}$ & $\mathrm{NR}_{2}$ & $\%$ yield & CCDC code & Ref. \\
\hline $\mathrm{Ph}$ & $\mathrm{NEt}_{2}$ & 45,39 & 622749 & 3 and 20 \\
\hline $\mathrm{Ph}$ & $\mathrm{N}(1-\text { naphthyl })_{2}$ & 58 & & 3 \\
\hline $\mathrm{Ph}$ & $\mathrm{N}^{n} \mathrm{Bu}_{2}$ & 57 & 677072 & 21 and 22 \\
\hline $\mathrm{Ph}$ & $\mathrm{NMe}_{2}$ & No data & & 22 \\
\hline $\mathrm{Ph}$ & $\mathrm{N}^{\mathrm{i}} \mathrm{Bu}_{2}$ & No data & & 23 \\
\hline $4-\mathrm{MeC}_{6} \mathrm{H}_{4}$ & morpholino & 64,93 & & 4,7 \\
\hline $4-\mathrm{MeC}_{6} \mathrm{H}_{4}$ & $\mathrm{NEt}_{2}$ & 100,96 & & 7 and 24 \\
\hline $2,6-\mathrm{F}_{2} \mathrm{C}_{6} \mathrm{H}_{3}$ & $\mathrm{~N}^{\mathrm{i}} \mathrm{Bu}_{2}$ & 60 & & 25 \\
\hline $2-\mathrm{FC}_{6} \mathrm{H}_{4}$ & $\mathrm{NEt}_{2}$ & 96 & 248406 & 26 \\
\hline $2-\mathrm{FC}_{6} \mathrm{H}_{4}$ & $\mathrm{~N}^{\mathrm{i}} \mathrm{Bu}_{2}$ & 68 & 248407 & 26 \\
\hline $4-\mathrm{O}_{2} \mathrm{NC}_{6} \mathrm{H}_{4}$ & $\mathrm{~N}^{\mathrm{i}} \mathrm{Bu}_{2}$ & 29 & 685384 & 27 \\
\hline 2-Naphthyl & $\mathrm{NEt}_{2}$ & 33 & 773721 & 28 \\
\hline $4-\mathrm{MeC}_{6} \mathrm{H}_{4}$ & $\mathrm{NMePh}$ & 64 & 791347 & 24 \\
\hline $\mathrm{Ph}$ & $\mathrm{NMePh}$ & 55 & 791348 & 24 \\
\hline $\mathrm{Ph}$ & Morpholino & 98 & & 4 \\
\hline $4-\mathrm{MeOC}_{6} \mathrm{H}_{4}$ & Morpholino & 91 & & 4 \\
\hline $4-\mathrm{ClC}_{6} \mathrm{H}_{4}$ & Morpholino & 85 & & 4 \\
\hline $4-\mathrm{O}_{2} \mathrm{NC}_{6} \mathrm{H}_{4}$ & Morpholino & 82 & & 4 \\
\hline $4-\mathrm{O}_{2} \mathrm{NC}_{6} \mathrm{H}_{4}$ & $\mathrm{NEt}_{2}$ & 33 & 852956 & 29 \\
\hline $4-\mathrm{ClC}_{6} \mathrm{H}_{4}$ & $\mathrm{~N}^{\mathrm{i}} \mathrm{Bu}_{2}$ & 71 & 1586977 & 30 \\
\hline $4-\mathrm{ClC}_{6} \mathrm{H}_{4}$ & $\mathrm{~N}^{n} \mathrm{Bu}_{2}$ & 24 & 1586975 & 30 \\
\hline
\end{tabular}

Subsequently, the same group reported detailed studies of mainly $\mathrm{Ni}^{(\mathrm{II})}$ and $\mathrm{Cu}^{(\mathrm{II})}$ bis(selenoureato) complexes. These investigations focused on EPR spectroscopy, ${ }^{34-39}$ ESCA spectroscopy, ${ }^{40,41}$ NMR spectroscopy ${ }^{42-44}$ as well as mass spectrometry. ${ }^{45,46}$ A summary of these results from the Beyer group was published in a review in $1983 .^{2}$ In the mid-1980's the group of König began investigating chromatographic metal separation using acylselenoureas as chelating agents and found that good separation with very low sensitivities (in the ng range) could be achieved. ${ }^{22,47,48}$ Even earlier, a Spanish group utilised the coloured products formed by the reaction of acylselenoureas with palladium or osmium salts for the spectrophotometric determination of these metals. Using the sarcosine derived

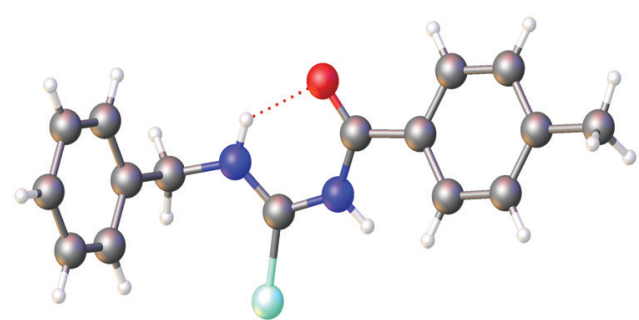

Fig. 3 Six-membered ring structure formed by an intramolecular $\mathrm{NH} \ldots \mathrm{O}$ hydrogen bond in the molecular structure of $p$-TolC(O)NHC(Se)NBz. Atom colours: mint - selenium, blue - nitrogen, red - oxygen, grey - carbon, white - hydrogen.

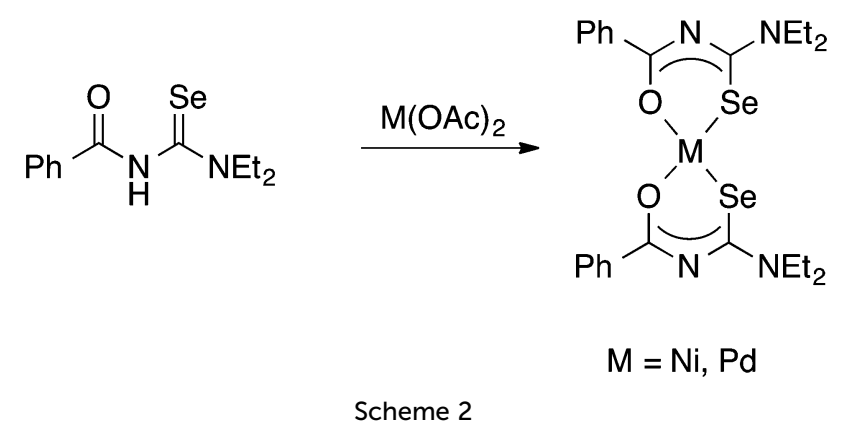

acylselenourea $\mathrm{PhC}(\mathrm{O}) \mathrm{NHC}(\mathrm{Se}) \mathrm{NHCH}_{2} \mathrm{C}(\mathrm{O}) \mathrm{OEt}$, palladium(II) could be determined in acidic solutions over a linear range of 4-16 $\mathrm{ppm}^{49}{ }^{4 \mathrm{Os}^{(\mathrm{VI})}}$ was also detected over a similar concentration range using the same acylselenourea. ${ }^{50}$ Similar results were also obtained using $\mathrm{PhC}(\mathrm{O}) \mathrm{NHC}(\mathrm{Se}) \mathrm{NHPh} .{ }^{51} \mathrm{~A}$ further example of the application of acylselenoureas in metal analysis is the spectrophotometric determination of $\mathrm{Ru}^{(\mathrm{III})}$ and $\mathrm{Os}^{(\mathrm{VI})}$ using $\mathrm{PhC}(\mathrm{O}) \mathrm{NHC}(\mathrm{Se}) \mathrm{NMePh} .{ }^{52}$ In all these examples however, the exact nature of the coloured species formed by interaction of the acylselenoureas with the metal ions was not further investigated.

In more recent times, various groups have explored the use of acylselenoureato metal complexes as single-source precursors for various metal selenide nanomaterials or thin films. The cadmium complex $\left[\mathrm{Cd}\left\{\mathrm{PhC}(\mathrm{O}) \mathrm{NC}(\mathrm{Se}) \mathrm{NEt}_{2}\right\}_{2}\right]$ was used by Koch for the preparation of cubic-phase CdSe nanoparticles via a controlled thermolysis method..$^{20}$ Similarly, the lead complexes $\left[\mathrm{Pb}\left\{\mathrm{PhC}(\mathrm{O}) \mathrm{NC}(\mathrm{Se}) \mathrm{NEt}_{2}\right\}_{2}\right], \quad\left[\mathrm{Pb}\left\{4-\mathrm{O}_{2} \mathrm{NC}_{6} \mathrm{H}_{4} \mathrm{C}(\mathrm{O}) \mathrm{NC}(\mathrm{Se}) \mathrm{N}^{\mathrm{i}} \mathrm{Bu}_{2}\right\}_{2}\right]$, $\left[\mathrm{Pb}\{2 \text {-napC(O)NC(Se)NEt }\}_{2}\right]$ as well as the $\mathrm{Pd}^{(\mathrm{II})}$ derivative 
<smiles>CCNC1=NC(c2ccccc2)=N[Se]2(O1)OC(NCC)=NC(c1ccccc1)=[Se]2</smiles>

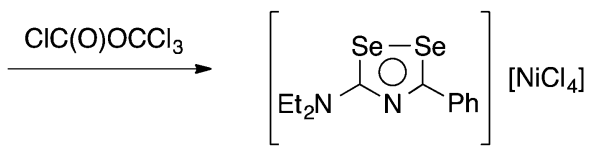

Scheme 3

$\left[\operatorname{Pd}\left\{2 \text {-napC }(\mathrm{O}) \mathrm{NC}(\mathrm{Se}) \mathrm{NEt}_{2}\right\}_{2}\right]$ were used as precursors for the deposition of PbSe or PdSe thin films. ${ }^{27,28,53-57}$ The same group also used the tris(chelate) iron(III) compound [Fe $\{2-n a p C(O)$ $\left.\mathrm{NC}(\mathrm{Se}) \mathrm{NEt}_{2}\right\}_{3}$ ] to obtain FeSe nanocrystals and thin films. ${ }^{58}$ The ferrocenyl-substituted selenourea $\left[3-\mathrm{FcC}_{6} \mathrm{H}_{4} \mathrm{NHC}(\mathrm{Se}) \mathrm{NHC}(\mathrm{O})-4\right.$ $\left.\mathrm{MeC}_{6} \mathrm{H}_{4}\right]$ was used as a single-source precursor to deposit FeSe nanoparticles on carbon nanotubes for photocatalytic applications. ${ }^{17}$ Our group has also studied the thermal behaviour of lead selenoureato bis(chelates) and the microwave-assisted formation of PbSe nanoparticles in ionic liquids. ${ }^{30}$

Limited data on the reactivity of bis(selenoureato) metal complexes is available. The $\mathrm{Ni}^{(\mathrm{II})}$ complex $\left[\mathrm{Ni}\left\{\mathrm{PhC}(\mathrm{O}) \mathrm{NC}(\mathrm{Se}) \mathrm{NEt}_{2}\right\}_{2}\right]$ reacts with diphosgene in benzene to afford a heterocyclic diselenazolium salt (Scheme 3), which was structurally characterised. ${ }^{59}$

Although the preparation of $N$-(thiocarbamoyl)benzimidoylchlorides by reaction of the $\mathrm{Ni}^{\text {(II) }}$ bis(thioureato) complexes $\left[\mathrm{Ni}\left\{\mathrm{PhC}(\mathrm{O}) \mathrm{NC}(\mathrm{S}) \mathrm{NR}_{2}\right\}_{2}\right]$ with $\mathrm{SOCl}_{2}$ proceeds in good yields, the analogous $N$-(selenocarbamoyl)benzimidoylchlorides cannot be prepared by this method; they are however readily accessible from direct reaction of the acylselenoureas with thiophosgene (Scheme 4). ${ }^{60}$ Such compounds can however be much easier prepared by reacting an imidoyl chloride with KSeCN and subsequent treatment with an amine (Scheme 5). ${ }^{61,62}$

The coordination chemistry of the diethyl derivative (HL in Scheme 5) has been investigated with various transition metals. ${ }^{62}$ Whilst its reactivity is generally very similar to that of the acylselenoureas, the structures of the chelate rings are considerably different. Whereas the acylselenoureato complexes feature almost planar chelate rings, the $N$-imidoselenoylcarbamato complexes display a boat-like conformation of the chelate rings. This difference has been attributed to a lesser degree of conjugation of the negative charge along the ligand backbone of the imodoyl derivatives, which was supported by DFT calculations.

Tetradentate acylselenoureas derived from isophthaloyl- and terephthaloylchloride are known, but were reported to be quite unstable. However, their $\mathrm{Ni}^{(\mathrm{II})}$ and $\mathrm{Cu}^{(\mathrm{II})}$ complexes (Scheme 6) could be isolated and were characterised by mass spectrometry, X-ray crystallography and EPR spectroscopy. ${ }^{39,63,64}$
From the early 1990's a series of papers reporting the X-ray crystal structures of various metal complexes with $\mathrm{PhC}(\mathrm{O}) \mathrm{NHC}-$ $(\mathrm{Se}) \mathrm{NEt}_{2}$ appeared. These include the main group metal complexes $\left[\mathrm{Tl}\left\{\mathrm{PhC}(\mathrm{O}) \mathrm{NC}(\mathrm{Se}) \mathrm{NEt}_{2}\right\}\right]_{2},{ }^{65}\left[\operatorname{In}\left\{\mathrm{PhC}(\mathrm{O}) \mathrm{NC}(\mathrm{Se}) \mathrm{NEt}_{2}\right\}_{3}\right]^{66}$ and $\left[\mathrm{Pb}\left\{\mathrm{PhC}(\mathrm{O}) \mathrm{NC}(\mathrm{Se}) \mathrm{NEt}_{2}\right\}_{2}\right]^{67}$ as well as the transition metal complexes $\left[\mathrm{Cd}\left\{\mathrm{PhC}(\mathrm{O}) \mathrm{NC}(\mathrm{Se}) \mathrm{NEt}_{2}\right\}_{2}\right],{ }^{68} \quad[\mathrm{Zn}\{\mathrm{PhC}(\mathrm{O}) \mathrm{NC}(\mathrm{Se})-$ $\left.\left.\mathrm{NEt}_{2}\right\}_{2}\right],{ }^{69}\left[\mathrm{Ni}\left\{\mathrm{PhC}(\mathrm{O}) \mathrm{NC}(\mathrm{Se}) \mathrm{NEt}_{2}\right\}_{2}\right]^{70}$ and $[\mathrm{Co}\{\mathrm{PhC}(\mathrm{O}) \mathrm{NC}(\mathrm{Se})-$ $\left.\left.\mathrm{NEt}_{2}\right\}_{3}\right]{ }^{71}$ The structure of the $\mathrm{Pd}^{(\mathrm{II})}$ bis(chelate) complex $\left[\operatorname{Pd}\left\{\operatorname{PhC}(\mathrm{O}) \mathrm{NC}(\mathrm{Se}) \mathrm{N}^{n} \mathrm{Bu}_{2}\right\}_{2}\right]$ as well as that of the selenourea itself was also communicated. ${ }^{21}$ Examples of selected structures are depicted in Fig. 4.

In all the structures mentioned above the deprotonated selenourea ligands adopt the cis O,Se-chelating coordination mode. To the best of our knowledge there is only one known compound in which two chelating acylselenoureas coordinate to a metal in a trans fashion: Crystals of the gallium(III)chlorido complex $\left[\mathrm{GaCl}\left\{4-\mathrm{O}_{2} \mathrm{NC}_{6} \mathrm{H}_{4} \mathrm{C}(\mathrm{O}) \mathrm{NC}(\mathrm{Se}) \mathrm{NEt}_{2}\right\}_{2}\right]$ (Fig. 4b) were obtained during attempts to prepare the corresponding tris(chelate). ${ }^{72}$

Over the past years we also reported the first examples of metal complexes in which the acylselenoureato ligands coordinate to a metal only via selenium (Fig. 5). These include the mono- and dinuclear gold(I) complexes containing phosphines or N-heterocyclic carbene co-ligands. ${ }^{73,74}$ In the X-ray structures of these complexes the acylselenoureato moiety is rotated in such a way, that the hard oxygen atom points away from the soft metal centre. These gold(I) complexes were also amongst the first examples of heteroleptic acylselenourea complexes in which there are additional ligands present in the coordination sphere of the metal.

We have subsequently reported the preparation and structural characterisation of organopalladium(II) compounds containing chelating acylselenourea ligands as well as monoanionic $\mathrm{C}-\mathrm{N}$ or $\mathrm{C}-\mathrm{Se}$ ligands by cleavage reactions of acetate- or chloro-bridged cyclopalladated species with the corresponding acylselenoureas (Scheme 7). ${ }^{75,76}$ Similarly, the polymeric organogold(III) compound $\left[\mathrm{AuCl}\left({ }^{t} \mathrm{Bu}_{2} \mathrm{Bip}\right)\right]_{n}$ containing a dicarbanionic biphenylderivative reacts with acylselenoureas in the presence of base, giving the corresponding chelate complexes (Scheme 7 ). ${ }^{77}$ It is important to note, that the carbanionic ligand stabilises the gold(III) oxidation state in these complexes. Reactions of acylselenoureas with gold(III) salts typically lead to reduction of the gold species and oxidation of the selenium compound. Cationic $\mathrm{Pd}^{(\mathrm{II})}$ and $\mathrm{Pt}^{(\mathrm{II})}$ complexes of the type $\left[\mathrm{M}\left\{\mathrm{ArC}(\mathrm{O}) \mathrm{NC}(\mathrm{Se}) \mathrm{NR}_{2}\right\}\right.$ $(\mathrm{L}-\mathrm{L})]^{+}(\mathrm{M}=\mathrm{Pd}, \mathrm{Pt})$ featuring bidentate nitrogen- (bipyridine, phenanthroline) or phosphorus-ligands (dppe or $\left.\mathrm{PPh}_{3}\right)$ and monoanionic acylselenoureato ligands have been prepared

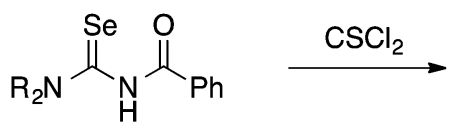

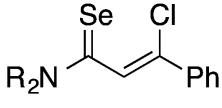

Scheme 4
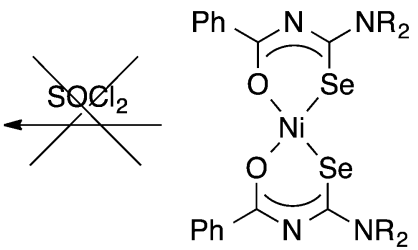
<smiles>Cc1ccc(NC(=O)c2ccccc2)cc1</smiles>

1. $\mathrm{SOCl}_{2}$

2. $\mathrm{KSeCN}$

3. $\mathrm{Et}_{2} \mathrm{NH}$<smiles>CCNC(=[Se])/N=C(\Nc1ccc(C)cc1)c1ccccc1</smiles>

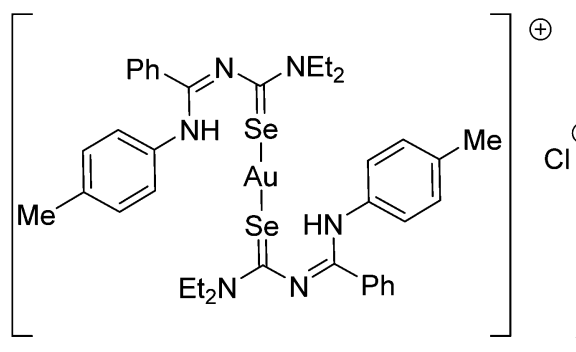<smiles>CCCC</smiles><smiles></smiles><smiles>CCNC1=NC(c2ccccc2)=NN(c2ccc(C)cc2)C(c2ccccc2)=N1</smiles>

HL<smiles>CCNC(/N=C(\Nc1ccc(C)cc1)c1ccccc1)=[Se][Ga]Cl</smiles><smiles>C#[W]</smiles><smiles>[3H]C</smiles><smiles>CCNC1=NC(c2ccccc2)N(c2ccc(C)cc2)[Te]2(c3ccccc3)(c3ccccc3N(C)N2C)N1C</smiles><smiles></smiles>

Scheme 5 (i) $\mathrm{Ni}(\mathrm{OAc})_{2}$. (ii) $\left[\mathrm{PdCl}_{2}\left({ }^{\mathrm{t}} \mathrm{Bu}_{2}\right.\right.$ bipy)], $\mathrm{Et}_{3} \mathrm{~N}, \mathrm{NH}_{4} \mathrm{PF}_{6}$. (iii) $\left[\mathrm{Pd}(\mathrm{OAc})\left\{\mathrm{C}_{6} \mathrm{H}_{4} \mathrm{~N}(\mathrm{Me}) \mathrm{N}=\mathrm{O}\right\}\right]_{2}$. (iv) 0.5 eq. $\mathrm{H}\left[\mathrm{AuCl}_{4}\right]$ or $\left[\mathrm{AuCl}\left(\mathrm{SMe}_{2}\right)\right]$. (v) $\mathrm{Standing}$ in $\mathrm{CDCl}$. (vi) 0.5 eq. $\left[\mathrm{AuCl}\left(\mathrm{SMe}_{2}\right)\right]$.<smiles>[R2]C(=[Se])NC(=O)c1cccc(C(=O)NC([NH-])=[SeH])c1</smiles>

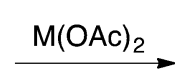

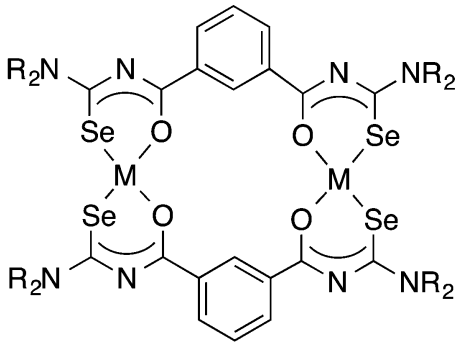

$\mathrm{M}=\mathrm{Ni}, \mathrm{Cu} ; \mathrm{R}=\mathrm{Et}$, 'Bu

Scheme 6

and structurally characterised (Scheme 7). ${ }^{24,78}$ The reaction of $\left[\mathrm{RuCl}_{2}(p \text {-cym })\right]_{2}$ with acylselenoureas and $\mathrm{Ph}_{3} \mathrm{P}$ in the presence of $\mathrm{NH}_{4} \mathrm{PF}_{6}$ afforded good yields of the organoruthenium(II) cations $\left[\mathrm{M}\left\{\operatorname{ArC}(\mathrm{O}) \mathrm{NC}(\mathrm{Se}) \mathrm{NR}_{2}\right\}(p \text {-cym })\left(\mathrm{PPh}_{3}\right)\right]^{+}$, which were fully characterised including several X-ray structures (Scheme 7). ${ }^{78}$ These complexes are chiral at the metal centre and feature four different ligating atoms (Se, O, P, and C) bound to ruthenium. In addition to structural data, we have collected detailed NMR spectroscopic data, in particular ${ }^{77}$ Se chemical shifts for both the acylselenoureas and the metal complexes. Studies of the biological activity of some of these substances against various tumour cell lines were also undertaken. ${ }^{29,78}$ 
a)

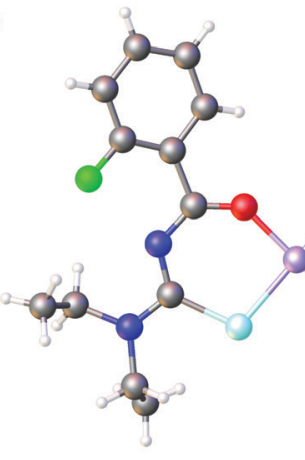

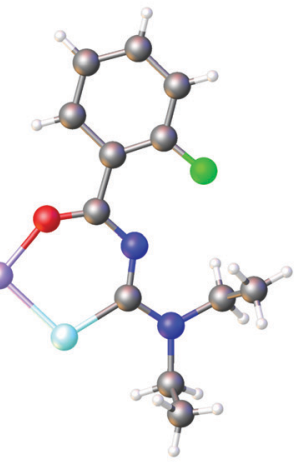

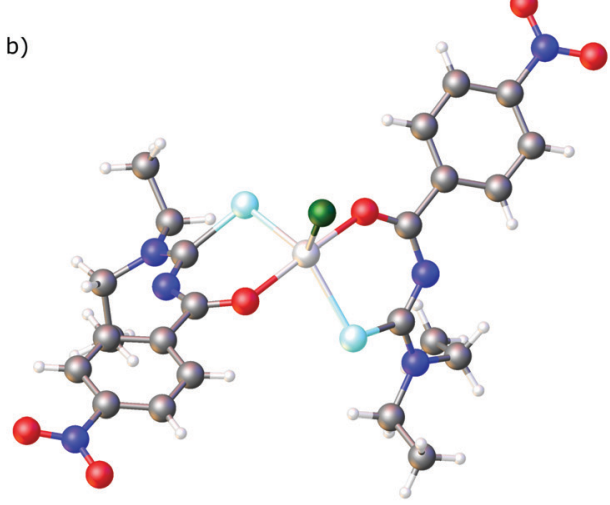

Fig. 4 (a) Molecular structure of $\left[\mathrm{Ni}\left\{\left(2-\mathrm{FC}_{6} \mathrm{H}_{4}\right) \mathrm{C}(\mathrm{O}) \mathrm{NC}(\mathrm{Se}) \mathrm{NEt}_{2}\right\}\right]_{2}$. (b) Molecular structure of $\left[\mathrm{GaCl}\left\{4-\mathrm{O}_{2} \mathrm{NC}_{6} \mathrm{H}_{4} \mathrm{C}(\mathrm{O}) \mathrm{NC}(\mathrm{Se}) \mathrm{NEt}\right\}_{2}\right]$. Atom colours: mint selenium, blue - nitrogen, red - oxygen, grey - carbon, lilac - nickel, light grey - gallium, light green - fluorine, dark green - chlorine, white hydrogen.
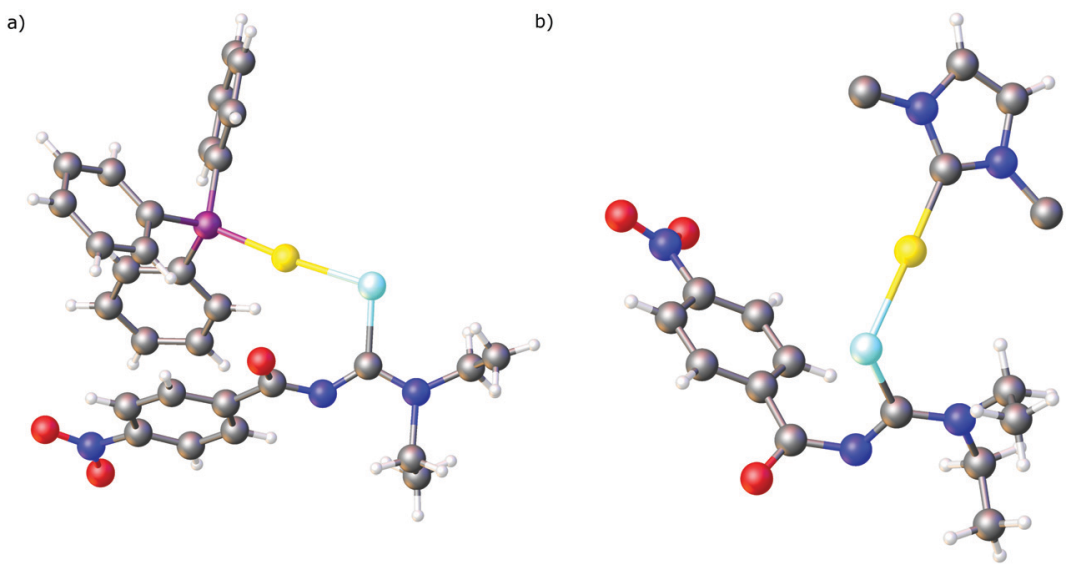

Fig. 5 (a) Molecular structure of $\left[\mathrm{Au}\left(\mathrm{PPh}_{3}\right)\left\{4-\mathrm{O}_{2} \mathrm{NC}_{6} \mathrm{H}_{4} \mathrm{C}(\mathrm{O}) \mathrm{NC}(\mathrm{Se}) \mathrm{NEt}_{2}\right\}\right]$. (b) Molecular structure of $\left[\mathrm{Au}(\mathrm{IPr})\left\{4-\mathrm{O}_{2} \mathrm{NC} \mathrm{C}_{6} \mathrm{H}_{4} \mathrm{C}(\mathrm{O}) \mathrm{NC}(\mathrm{Se}) \mathrm{NEt} t_{2}\right\}\right]$. Only the ipso-carbon atoms of the 2,6-('Pr) ${ }_{2} \mathrm{C}_{6} \mathrm{H}_{3}$ groups are shown. Atom colours: mint - selenium, blue - nitrogen, red - oxygen, magenta - phosphorous, grey - carbon, yellow - gold, white - hydrogen.

The results of a study of the reactivity of some acylselenoureas with the oxorhenium(v) salt ${ }^{n} \mathrm{Bu}_{4} \mathrm{~N}\left[\mathrm{ReOCl}_{4}\right]$ have also been reported. ${ }^{79}$ Depending on the reaction conditions, different metal complexes were isolated and structurally characterised. In most cases, the deprotonated acylselenourea adopts the typical O,Se-chelating mode. However, one complex was isolated in which two of the three acylselenoureato ligands are chelating whilst the third bonds to the ReO-core only through the selenium atom (Fig. 6).

More recently we found, that $\mathrm{Ag}_{2} \mathrm{O}$ dissolves in a solution of acylselenoureas, forming tetranuclear silver(I) clusters $\left[\mathrm{Ag}_{4}\left\{\mathrm{ArC}(\mathrm{O}) \mathrm{NC}(\mathrm{Se}) \mathrm{NEt}_{2}\right\}_{4}\right]$ containing the deprotonated acylselenoureato ligands (Fig. 7a). ${ }^{80}$ These clusters react with four or eight equivalents of a phosphine affording dinuclear $\mathrm{Ag}^{(\mathrm{I})}$ compounds $\left[\mathrm{Ag}_{2}\left\{\operatorname{ArC}(\mathrm{O}) \mathrm{NC}(\mathrm{Se}) \mathrm{NEt}_{2}\right\}_{2}(\mathrm{P})_{2}\right]$ or the mononuclear complexes $\left[\mathrm{Ag}\left\{\mathrm{ArC}(\mathrm{O}) \mathrm{NC}(\mathrm{Se}) \mathrm{NEt}_{2}\right\}(\mathrm{P})_{2}\right]\left(\mathrm{P}=\mathrm{Ph}_{3} \mathrm{P}\right.$, PTA), respectively (Scheme 8).

Although acylselenoureato complexes of copper(II) have long been known and are well-studied, their $\mathrm{Cu}^{(\mathrm{I})}$ counterparts were only reported recently. The phosphine and N-heterocyclic carbene $\mathrm{Cu}^{(\mathrm{I})}$ compounds $\left[\mathrm{Cu}\left\{\mathrm{ArC}(\mathrm{O}) \mathrm{NC}(\mathrm{Se}) \mathrm{NEt}_{2}\right\}\left(\mathrm{Ph}_{3} \mathrm{P}\right)_{2}\right](\mathrm{Fig} .7 \mathrm{~b})$ and $\left[\mathrm{Cu}\left\{\operatorname{ArC}(\mathrm{O}) \mathrm{NC}(\mathrm{Se}) \mathrm{NEt}_{2}\right\}(\mathrm{IPr})\right]$ containing deprotonated chelating acylselenourea ligands are readily prepared from the acylselenoureas and the copper(I) compounds [CuCl(IPr)] or $\left[\mathrm{Cu}\left(\mathrm{Ph}_{3} \mathrm{P}\right)_{2}\right] \mathrm{NO}_{3}{ }^{81}$ The presence of the co-ligands is essential in this case to stabilise the copper(I) oxidation state.

\section{Selenosemicarbazones}

Selenosemicarbazones $\quad \mathrm{RR}^{\prime} \mathrm{C}=\mathrm{NNHC}(\mathrm{Se}) \mathrm{NH}_{2}$ were first reported in the 1950 's by Huls and Renson. ${ }^{82,83}$ By varying the nature of the substituents on the imine carbon atom, a large number of derivatives can be synthesised. Such selenosemicarbazones are accessible from the condensation of acetone selenosemicarbazone, cyclohexanone selenosemicarbazone or selenosemicarbazide with an aldehyde or ketone. Whilst selenosemicarbazide $\mathrm{H}_{2} \mathrm{NC}(\mathrm{Se}) \mathrm{NHNH}_{2}$ was commercially available, 


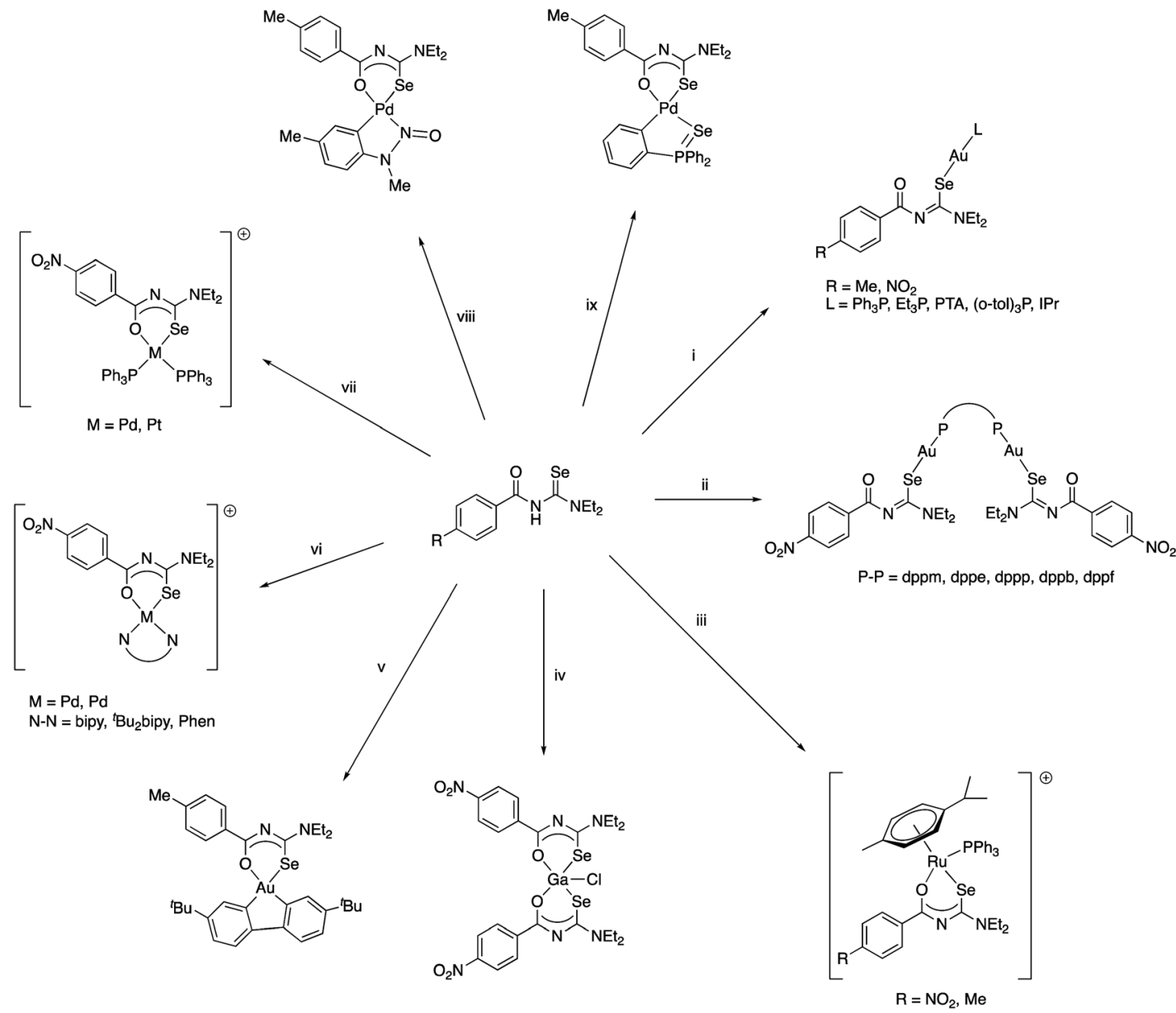

Scheme 7 (i). $[\mathrm{AuCl}(\mathrm{L})]\left(\mathrm{L}=\mathrm{Ph}_{3} \mathrm{P}, \mathrm{Et}_{3} \mathrm{P}, \mathrm{PTA}, \mathrm{P}(\mathrm{o}-\mathrm{tol})_{3}, \mathrm{IPr}\right)$, base. (ii) $\left[\mathrm{Au}_{2} \mathrm{Cl}_{2}(\mathrm{P}-\mathrm{P})\right](\mathrm{P}-\mathrm{P}=\mathrm{dppm}, \mathrm{dppb}, \mathrm{dppp}, \mathrm{dppb}, \mathrm{dppf}), \mathrm{NaOAc}$. (iii) $[\mathrm{RuCl} \text { ( }(p-\mathrm{cym})]_{2}$, $\mathrm{PPh}_{3}, \mathrm{Et}_{3} \mathrm{~N}, \mathrm{NaBPh}_{4}$. (iv) $\mathrm{GaCl}_{3}, \mathrm{EtOH}$. (v) $\left.\left[\mathrm{AuCl}^{t} \mathrm{BBu}_{2} \mathrm{Bip}\right)\right]_{n}, \mathrm{NaOMe}$. (vi) $\mathrm{Cis}-\left[\mathrm{MCl}_{2}(\mathrm{~N}-\mathrm{N})\right](\mathrm{M}=\mathrm{Pd}, \mathrm{Pt}) ; \mathrm{N}-\mathrm{N}=$ bipy.

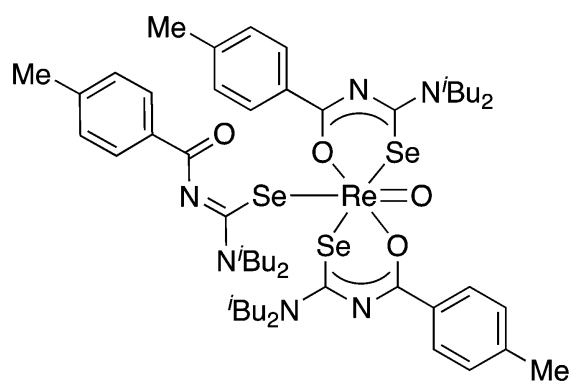

Fig. 6 An oxorhenium(v) complex containing both anionic Se,Ochelating and neutral Se-bound acylselenourea ligands.

acetone selenosemicarbazone $\mathrm{e}^{82-84}$ or the more stable cyclohexanone selenosemicarbazone ${ }^{85}$ can be prepared in reasonable yields from the reaction of $\mathrm{KSeCN}$ with hydrazine hydrate in the presence of the ketone under acidic conditions. We have published an improved, reproducible preparation for this synthon together with its X-ray crystal structure. ${ }^{86}$ If the substituent on the imine carbon carries a potential donor atom, a functionalised selenosemicarbazone is obtained. For the purpose of this article, a compound of the type $\mathrm{D}-\mathrm{CR}=\mathrm{NNHC}(\mathrm{Se}) \mathrm{NH}_{2}$, where $\mathrm{D}$ represents a donor atom $(\mathrm{N}, \mathrm{O}$ or $\mathrm{P})$ shall be defined as a functionalised selenosemicarbazone. Thus, in the following discussion the selenosemicarbazones are grouped according to the type of donor atom.

\subsection{Complexes of selenosemicarbazones containing no additional donor atoms}

The very first report of a selenosemicarbazone as ligand in a metal complex dates back to 1968. The group of Gerbeleu showed that cyclohexanone selenosemicarbazone or benzaldehyde selenosemicarbazone act as neutral Se-donors in octahedral $\mathrm{Co}^{(\mathrm{III})}$ complexes containing dimethylglyoximato ligands forming either complexes of the type $\left[\mathrm{CoCl}(\mathrm{DMG})_{2}(\mathrm{HLSe})\right]$ or $\left[\mathrm{Co}(\mathrm{DMG})_{2}(\mathrm{HLSe})_{2}\right]^{+}(\mathrm{DMG}=$ dimethylglyoximato; HLSe $=$ neutral selenosemicarbazone), depending on the reaction stoichiometry. ${ }^{87}$ Acetone selenosemicarbazone or cyclohexanone selenosemicarbazone react with divalent nickel salts in the presence of base to afford diamagnetic, square planar complexes of the type $\left[\mathrm{Ni}(\mathrm{LSe})_{2}\right](\mathrm{LSe}=$ monoanionic selenosemicarbazone $) .{ }^{88}$ Here the deprotonated selenosemicarbazones coordinate to the metal as monoanionic $[\mathrm{N}, \mathrm{Se}]^{-}$ligands. In the absence of a base, the 


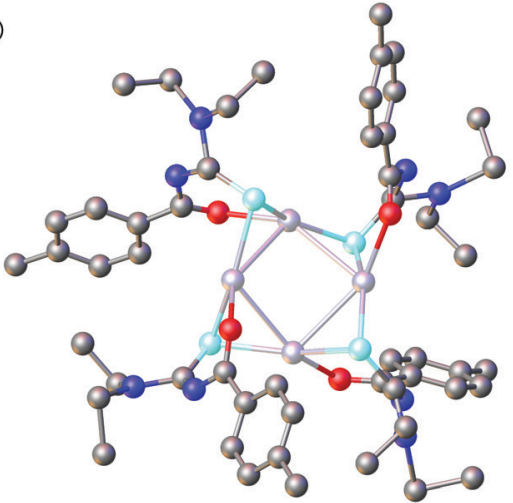

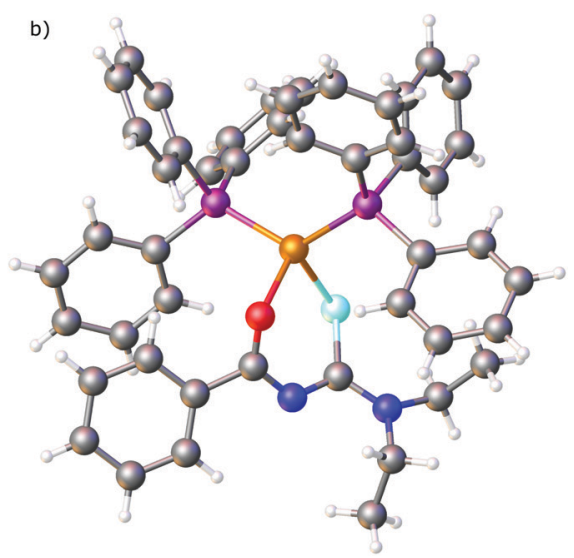

Fig. 7 (a) Molecular structure of $\left[\mathrm{Ag}_{4}\left\{\mathrm{PhC}(\mathrm{O}) \mathrm{NC}(\mathrm{Se}) \mathrm{NEt}_{2}\right\}_{4}\right]$. Hydrogen atoms have been omitted for clarity. (b) Molecular structure of $\left[\mathrm{Cu}\left(\mathrm{Ph}_{3} \mathrm{P}\right)_{2}\left\{\mathrm{PhC}(\mathrm{O}) \mathrm{NC}(\mathrm{Se}) \mathrm{NEt}_{2}\right\}\right]$. Atom colours: mint - selenium, blue - nitrogen, red - oxygen, grey - carbon, magenta - phosphorous, light greysilver, orange - copper, white - hydrogen.<smiles>CCNC(=O)NC(=O)c1ccc(C)cc1</smiles>

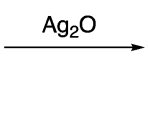
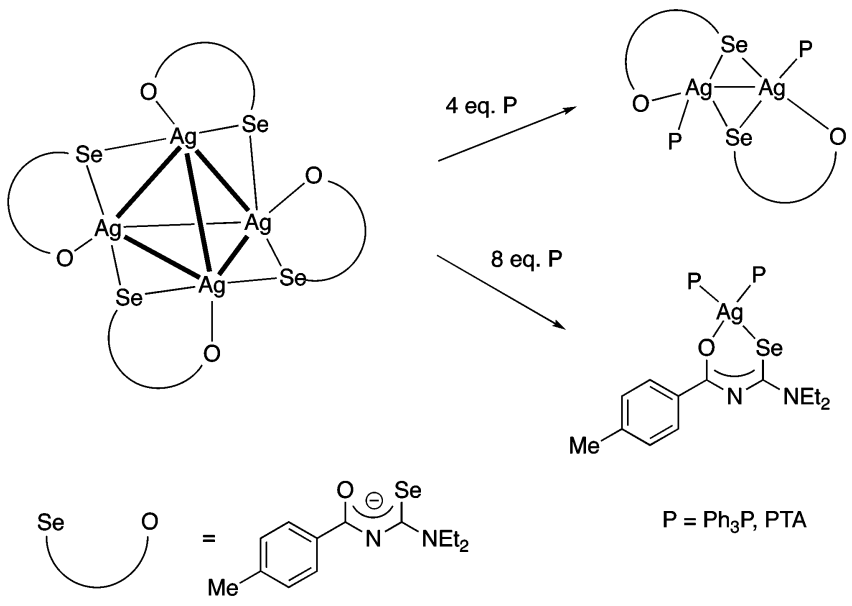

$\mathrm{P}=\mathrm{Ph}_{3} \mathrm{P}, \mathrm{PTA}$

Scheme 8

chelate complexes $\left[\mathrm{NiCl}_{2}(\mathrm{HSe})\right]$ or $\left[\mathrm{ZnCl}_{2}(\mathrm{HSe})\right]$ containing neutral selenosemicarbazone ligands are formed with $\mathrm{Ni}^{2+}$ and $\mathrm{Zn}^{2+}$ ions, respectively. ${ }^{88} \mathrm{~A}$ series of octahedral nickel(II) and cobalt(II) complexes containing thio- or selenocyanato ligands as well as neutral, Se-bound selenosemicarbazones $\left[\mathrm{M}(\mathrm{NCE})_{2}(\mathrm{HLSe})_{4}\right](\mathrm{M}=$ $\mathrm{Ni}, \mathrm{Co} ; \mathrm{E}=\mathrm{S}, \mathrm{Se}$ ) was reported by Gerbeleu. ${ }^{89}$ Through detailed IR-spectroscopic studies it was established that the chalcogenocyanate ligands are N-bound to the metal. In 1983 three papers on the coordination chemistry of acetone selenosemicarbazone and furfural selenosemicarbazone with nickel(II) and cadmium(II) were published. In these compounds the ligands also act as monoanionic $[\mathrm{N}, \mathrm{Se}]^{-}$ligands, forming bis(chelates) with the divalent metal centres. This structural assignment was however solely based on spectroscopic data. ${ }^{90-92}$

\subsection{Complexes of selenosemicarbazones containing oxygen donor atoms}

Oxygen functionalised selenosemicarbazones derived from salicylaldehyde, adipoin, 2-hydroxy-1-naphthaldehyde, pyruvic acid, phenylglyoxalic acid and diacetyl monoxime have been prepared and used as ligands in coordination chemistry (Fig. 8).

Salicylaldehyde selenosemicarbazone (abbreviated here as $\mathrm{H}_{2} \mathrm{SeL}^{\text {sal }}$ ) reacts with $\mathrm{Co}^{3+}, \mathrm{Cr}^{3+}$ and $\mathrm{Fe}^{3+}$ ions in the presence of a base to form octahedral salts of the type $\left[\mathrm{M}\left(\mathrm{SeL}^{\mathrm{sal}}\right)_{2}\right]^{-}$, in which the salicylaldehyde selenosemicarbazone acts as a dianionic, tridentate $[\mathrm{O}, \mathrm{N}, \mathrm{Se}]^{2-}$ ligand bound to the metal via the phenolic oxygen-, imine nitrogen- and selenium-atoms. ${ }^{93}$ Similarly, with $\mathrm{CuCl}_{2}$ in the presence of pyridine, the diamagnetic, square planar complex $\left[\mathrm{Cu}\left(\mathrm{SeL}^{\mathrm{sal}}\right)(\mathrm{Py})\right]$ is obtained, in which $[\mathrm{O}, \mathrm{N}, \mathrm{Se}]^{2-}$ coordination is also observed. ${ }^{94}$ The pyridine ligand can be substituted by bidentate $\mathrm{N}$-donors such as 1,10phenanthroline or $2,2^{\prime}$-bipyridine to give the five-coordinate complexes $\left[\mathrm{Cu}\left(\mathrm{SeL}^{\mathrm{Sal}}\right)(\mathrm{N}-\mathrm{N})\right](\mathrm{N}-\mathrm{N}=1,10$-phenanthroline or $2,2^{\prime}$-bipyridine). With vanadyl sulfate, salicylaldehyde selenosemicarbazone shows some unexpected reactivity: when ammonia or $\mathrm{KOH}$ are used as base and one additional equivalent of salicylaldehyde is present, an oxovanadium(Iv) salt is formed, 
<smiles>NC(=[Se])N/N=C/c1ccccc1O</smiles><smiles>NC(=[Se])N/N=C/[C@H]1CCCC[C@@H]1O</smiles><smiles>NC(=[Se])N/N=C/c1c(O)ccc2ccccc12</smiles><smiles>C/C(=N\NC(N)=[Se])C(=O)O</smiles><smiles>NC(=[Se])NN=C(O)c1ccccc1</smiles><smiles>CC(=NNC(N)=[Se])/C(C)=N\O</smiles>

Fig. 8 Examples of functionalised selenosemicarbazones containing oxygen donor atoms.

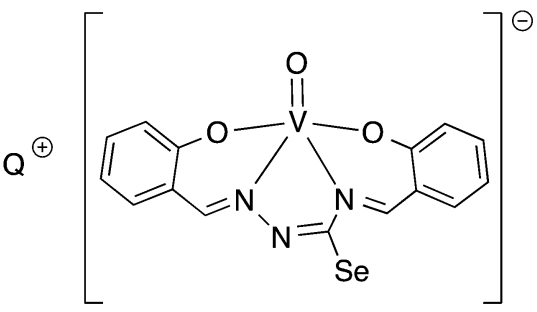

Fig. 9 Vanadyl salt formed by template condensation of salicylaldehyde selenosemicarbazone with salicylaldehyde $\left(\mathrm{Q}=\mathrm{NH}_{4}, \mathrm{~K}\right)$.

which contains the condensation product of salicylaldehyde selenosemicarbazone with salicylaldehyde (Fig. 9). ${ }^{95}$ In this case, the resulting tetradentate macrocycle coordinates to the metal only through the imine nitrogen atoms and the phenolic oxygen atoms. The selenium atom does not interact with the metal. The same template condensation process is also observed in complexes with $\mathrm{Ni}^{\text {(II) }}$ and $\mathrm{Cu}^{(\mathrm{II})}$ when $\mathrm{NaOH}$ or $\mathrm{KOH}$ are used as base. ${ }^{96}$

In the presence of pyridine or bidentate $\mathrm{N}$-donors, sixcoordinate $\mathrm{V}^{(\mathrm{IV})}$ complexes with the $[\mathrm{O}, \mathrm{N}, \mathrm{Se}]^{2-}$ coordination mode of salicylaldehyde selenosemicarbazone have been proposed. ${ }^{95}$ However, based on a crystal structure determination, we have observed that in such systems salicylaldehyde selenosemicarbazone in fact acts as a dianionic $[\mathrm{O}, \mathrm{N}, \mathrm{N}]^{2-}$ ligand (Fig. 10), with the selenium atom not bound to the metal. ${ }^{97}$ Given that the vanadyl ion is classified as a hard base, it is perhaps not surprising, that the soft selenium atom does not coordinate to vanadium.

The group of Gerbeleu also reported the first X-ray structure of a metal complex containing salicylaldehyde selenosemicarbazone, which confirmed that the compound indeed acts as a dianionic, tridentate $[\mathrm{O}, \mathrm{N}, \mathrm{Se}]^{2-}$ ligand in the nickel(II) complex $\left[\mathrm{Ni}\left(\mathrm{SeL}^{\mathrm{Sal}}\right)\left(\mathrm{PPh}_{3}\right)\right]$ (Fig. 11). ${ }^{98,99}$

Structurally related to salicylaldehyde selenosemicarbazone is adipoin selenosemicarbazone, which is reported to form

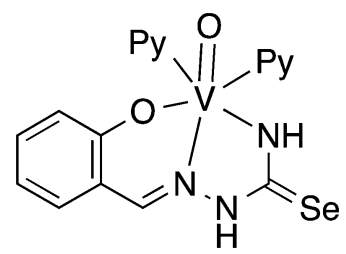

Fig. 10 Salicylaldehyde selenosemicarbazone as a dianionic $[\mathrm{O}, \mathrm{N}, \mathrm{N}]^{2-}$ ligand. analogous complexes with $\mathrm{Co}^{3+}, \mathrm{Ni}^{2+}, \mathrm{Zn}^{2+}$ and $\mathrm{Cu}^{2+}$ ions. ${ }^{100,101}$ These compounds however, were reported to be less stable than their salicylaldehyde selenosemicarbazone counterparts.

The selenosemicarbazones derived from pyruvic acid and phenylglyoxalic acid both contain a carboxylic acid functional group, which upon deprotonation may coordinate to a metal centre (in addition to the $\mathrm{N}$ - and Se-atoms of the selenosemicarbazone). Although no structural data has so far been reported, the group of Gerbeleu has studied the coordination chemistry of these selenosemicarbazones with various metals. The selenosemicarbazone derived from pyruvic acid forms oxovanadium(Iv) complexes in the presence of pyridine or 3-picoline, similar to those with salicylaldehyde selenosemicarbazone. $^{95}$ Other complexes containing pyruvic acid or phenylglyoxalic acid selenosemicarbazone with $\mathrm{Co}^{3+}, \mathrm{Ni}^{2+}$, $\mathrm{Cu}^{2+}, \mathrm{Fe}^{3+}, \mathrm{Fe}^{2+}$ and $\mathrm{Cr}^{3+}$ have also been investigated. ${ }^{102,103}$ In each case, in the presence of a base, the selenosemicarbazones act as dianionic, tridentate [O,N,Se $]^{2-}$ ligands (Fig. 12).

Although the selenosemicarbazone derived from diacetyl monoxime $\mathrm{MeC}(\mathrm{NOH}) \mathrm{C}(\mathrm{Me}) \mathrm{NNHC}(\mathrm{Se}) \mathrm{NH}_{2}$ (abbreviated here as $\mathrm{H}_{2} \mathrm{SeL}^{\mathrm{Ox}}$ ) contains a hydroxy group, there is so far no evidence that the oxygen atom coordinates to a metal centre. In a series of papers, the group of Gerbeleu reported the coordination chemistry of this ligand with copper, nickel, cobalt and iron. The selenosemicarbazone reacts with copper(II) salts to give green, paramagnetic complexes of the type $\left[\mathrm{CuX}_{2}\left(\mathrm{H}_{2} \mathrm{SeL}^{\mathrm{Ox}}\right)\right]$ $(\mathrm{X}=\mathrm{Cl}, \mathrm{Br}$ ), in which the neutral ligand is bound to the metal

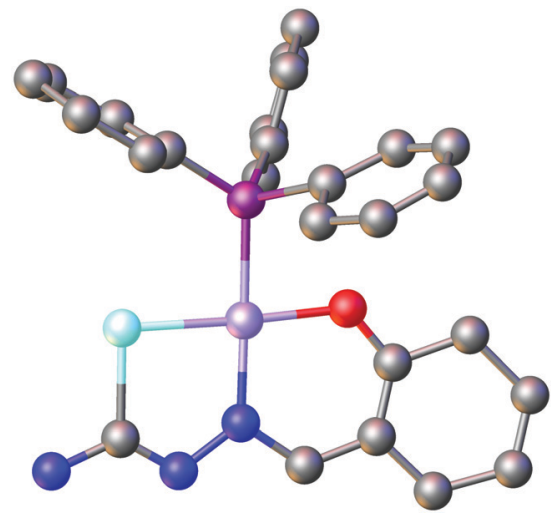

Fig. 11 Molecular structure of $\left[\mathrm{Ni}\left(\mathrm{SeL}^{\mathrm{sal}}\right)\left(\mathrm{PPh}_{3}\right)\right]$. Hydrogen atoms have been omitted for clarity. Atom colours: mint - selenium, blue - nitrogen, red - oxygen, grey - carbon, magenta - phosphorous, lilac - nickel. 
<smiles></smiles>

$$
\mathrm{R}=\mathrm{Me}, \mathrm{Ph}
$$

Fig. 12 Schematic illustration of the proposed coordination mode of the doubly deprotonated selenosemicarbazones of pyruvic acid or phenylglyoxalic acid.

through the nitrogen atoms of the oxime and imine and the selenium atom. ${ }^{104}$ In the presence of one equivalent of sodium acetate the hydroxy-group of the ligand is deprotonated and compounds formulated as $\left[\mathrm{CuX}\left(\mathrm{HSeL}^{\mathrm{Ox}}\right)\right](\mathrm{X}=\mathrm{Cl}, \mathrm{Br})$ were isolated. With an excess of sodium acetate, a poorly soluble brown complex containing the doubly deprotonated ligand was obtained. With nickel(II) salts in the absence of base, brown paramagnetic products containing the octahedral cations $\left[\mathrm{Ni}\left(\mathrm{H}_{2} \mathrm{SeL}^{\mathrm{Ox}}\right)_{2}\right]^{2+}$ are formed. If the reaction was carried out in aqueous ammonia a brown diamagnetic product formed, which was formulated as the square planar species $\left[\mathrm{Ni}\left(\mathrm{SeL}^{\mathrm{Ox}}\right)\left(\mathrm{NH}_{3}\right)\right]^{105}$ When nickel(II) acetate is used in the reaction, a poorly soluble diamagnetic material was isolated. In the latter two complexes, the doubly deprotonated selenosemicarbazone is bound to the metal through the nitrogen atoms of the oxime and imine and the selenium atom. Cobalt(II) salts react with the selenosemicarbazone under aerobic conditions to give the octahedral cobalt(III) salts $\left[\mathrm{Co}\left(\mathrm{HSeL}^{\mathrm{Ox}}\right)_{2}\right] \mathrm{X}\left(\mathrm{X}=\mathrm{Cl}, \mathrm{Br}, \mathrm{I}, \mathrm{NO}_{3}, \mathrm{NCS}\right) .{ }^{106}$ Under strictly anaerobic conditions some $\mathrm{Co}^{(\mathrm{II})}$ compounds could also be isolated, but their instability prevented detailed characterisation. Similar reactions were examined with iron(II) and iron(III) salts. ${ }^{106}$ With hydrated $\mathrm{CrCl}_{3}$ a material was isolated, which was formulated as the neutral octahedral species $\left[\mathrm{Cr}\left(\mathrm{SeL}^{\mathrm{Ox}}\right)\left(\mathrm{HSeL}^{\mathrm{Ox}}\right)\right]$, containing one monoanionic and one dianionic selenosemicarbazone ligand. ${ }^{107}$ In all these examples, the proposed structures are based on elemental analysis, molar conductivity, magnetic measurements and powder diffraction data. To date there are however no reported X-ray structures of complexes containing this selenosemicarbazone to confirm the structures of any of the products discussed above.

\subsection{Complexes of selenosemicarbazones containing nitrogen donor atoms}

Selenosemicarbazones containing additional nitrogen donoratoms, which have been used as ligands, are derived from the condensation of selenosemicarbazide or its derivatives with 2-pyridinecarboxaldehyde, 2-acetylpyridine, 2-benzoylpyridine, 2-quinolinecarboxaldehyde or 8-quinolinecarboxaldehyde (Fig. 13).

The first reported metal complexes with nitrogenfunctionalised selenosemicarbazones date back to 1971 from the group of Gerbeleu. Reactions of the selenosemicarbazone derived from 8-quinolinecarboxaldehyde (abbreviated here as $\mathrm{HSeL}^{\text {8quin }}$ ) with $\mathrm{Co}^{(\mathrm{III})}, \mathrm{Ni}^{(\mathrm{II})}$ and $\mathrm{Cu}^{(\mathrm{II})}$ salts was examined. ${ }^{108,109}$ The selenosemicarbazone can displace the water molecule in trans-[CoCl$\left.(\mathrm{DMG})_{2}\left(\mathrm{H}_{2} \mathrm{O}\right)\right](\mathrm{DMG}=$ dimethylglyoximato $)$ to give the corresponding selenosemicarbazone complex in which the neutral ligand acts as a Se-donor. ${ }^{108}$ Interestingly, when the same reaction is carried out with two equivalents of the selenosemicarbazone both dimethylglyoximato ligands are displaced forming the octahedral cationic complex $\left[\mathrm{Co}\left(\mathrm{SeL}^{8 q u i n}\right)_{2}\right] \mathrm{Cl}$. In this compound, the deprotonated selenosemicarbazone binds to the metal through two nitrogen atoms (quinoline and imine) and the selenium atom. With nickel(II) salts paramagnetic octahedral salts $\left[\mathrm{Ni}\left(\mathrm{HSeL}^{8 q u i n}\right)_{2}\right] \mathrm{X}_{2}(\mathrm{X}=\mathrm{Cl}, \mathrm{Br}, \mathrm{I})$ and square planar diamagnetic compounds [NiX $\left.\left(\mathrm{SeL}^{8 q u i n}\right)\right]\left(\mathrm{X}=\mathrm{NCS}, \mathrm{NO}_{2}\right)$ were isolated. ${ }^{108}$ The latter compound forms in the presence of base. With copper(II) salts products of the type $\left[\mathrm{CuX}_{2}\left(\mathrm{HSeL}^{8 q u i n}\right)\right](\mathrm{X}=\mathrm{Cl}$, $\mathrm{Br}, \mathrm{NO}_{3}$ ) were formed but no reduction of the copper salt by the selenium compound was observed. ${ }^{109}$ The antibacterial and antifungal activity of these copper(II) complexes were subsequently studied, however neither the selenosemicarbazone nor its copper complexes were active. ${ }^{110}$ In 2016, the cationic cobalt(III) complex $\left[\mathrm{Co}\left(\mathrm{SeL}^{8 \mathrm{quin}}\right)_{2}\right] \mathrm{ClO}_{4}$ was prepared and fully characterised with modern spectroscopic methods. ${ }^{111}$ The X-ray structure unambiguously confirmed that the deprotonated selenosemicarbazone is bound to the metal through selenium- and two nitrogen-atoms. The complex showed considerable in vitro anticancer activity, and a variety of experiments (e.g. apoptosis induction, cell cycle changes and caspase activation) were carried out to determine possible mechanisms of action. ${ }^{111}$

The isomeric selenosemicarbazone derived from 2-quinolinecarboxaldehyde (abbreviated here as $\mathrm{HSeL}^{2 q u i n}$ ) forms complexes of the type $\left[\mathrm{MX}\left(\mathrm{SeL}^{2 \text { quin }}\right)\right](\mathrm{M}=\mathrm{Pt}, \mathrm{Pt} ; \mathrm{X}=\mathrm{Cl} ; \mathrm{M}=\mathrm{Cd}$, $\mathrm{X}=\mathrm{OAc})$ as well as the octahedral bis(chelates) $\left[\mathrm{M}\left(\mathrm{SeL}^{2 q u i n}\right)_{2}\right]$ $(\mathrm{M}=\mathrm{Ni}, \mathrm{Zn})$ and $\left[\mathrm{Co}\left(\mathrm{SeL}^{2 \text { quin }}\right)_{2}\right] \mathrm{ClO}_{4} \cdot{ }^{112-116}$ These compounds were tested for their anticancer activity and detailed experiments to elucidate their mode of action have been reported together with spectroscopic and structural data for several metal complexes and the selenosemicarbazone itself.

Several groups have studied the activity of 2-pyridyl-derived selenosemicarbazones as well as their metal complexes against Chagas disease and malaria. ${ }^{117-121}$ The coordination chemistry
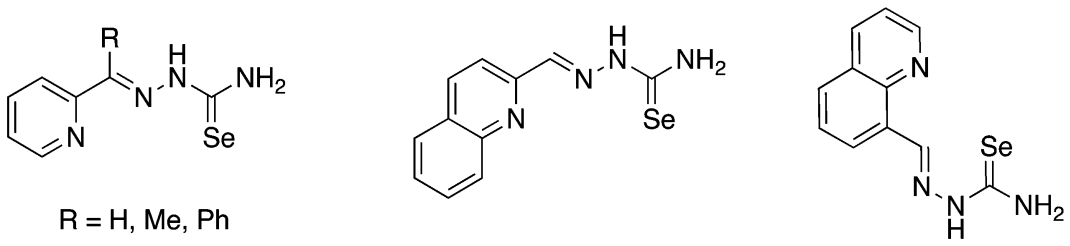

Fig. 13 Examples of functionalised selenosemicarbazones containing nitrogen donor atoms. 


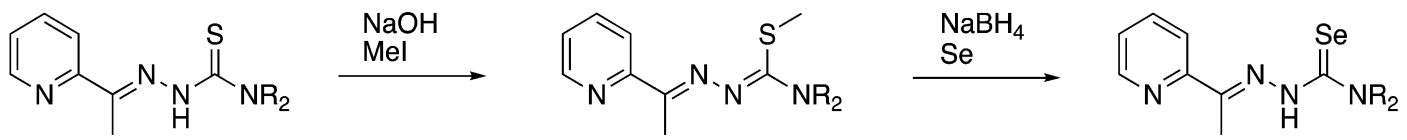

Scheme 9 Synthesis of $\mathrm{N} 4$-disubstituted 2-acetylpyridine selenosemicarbazones. $\mathrm{NR}_{2}$ can be derived from dialkyl amines, cyclic amines or bicyclic amines.

and biological activity of metal complexes containing selenosemicarbazones derived from 2-acetylpyridine ( $\mathrm{HSeL}^{\text {acpy }}$ ) have been investigated in some detail over the years. Structural diversity can be increased by varying the substituents on the nitrogen atom at the 4-position. The synthesis of these compounds involves $S$-methylation of the corresponding thiosemicarbazones and subsequent selenation using in situ generated $\mathrm{NaSeH}$ (Scheme 9). ${ }^{119,121}$

The octahedral iron(III) salt $\left[\mathrm{Fe}\left(\mathrm{LSe}^{\text {acpy }}\right)_{2}\right]\left[\mathrm{FeCl}_{4}\right]$ containing 2-acetylpyridine selenosemicarbazone substituted at the 4 position with the bicyclic amine 3-azabicyclo[3.2.2]nonane, was the first structurally authenticated metal complex containing an $N$-functionalised selenosemicarbazone. ${ }^{122}$ The same group also reported the corresponding square planar nickel(II) complex $\left[\mathrm{NiCl}\left(\mathrm{LSe}^{\text {acpy }}\right)\right]{ }^{123}$ Other groups described $\mathrm{Mn}^{(\text {II) }}$ as well as $\mathrm{Ni}^{(\text {II })}$ and $\mathrm{Cu}^{\text {(II) }}$ complexes with the same selenosemicarbazone. ${ }^{120,124}$

The N4-dimethyl derivative of 2-acetylpyridine selenosemicarbazone reacts with $\mathrm{Ga}\left(\mathrm{NO}_{3}\right)_{3}$ in the presence of $\mathrm{NH}_{4} \mathrm{PF}_{6}$ to afford the octahedral bis(chelate) salt $\left[\mathrm{Ga}\left(\mathrm{LSe}^{\mathrm{acpy}}\right)_{2}\right] \mathrm{PF}_{6} \cdot{ }^{125} \mathrm{X}$-ray structures for both the selenosemicarbazone and the gallium(II) complex were reported together with a study on the in vitro antitumor activity in two different cell lines. In a subsequent paper, the same group reported a more detailed study which also included the corresponding iron and ruthenium bis(chelate) salts. ${ }^{126}$ The authors demonstrated that the antitumor activity correlates with the atomic number of the chalcogen, the selenium compound thus being the most active compared to its sulfur and oxygen counterparts.

The mono- and dinuclear copper(II) complexes [Cu(OAc)$\left.\left(\mathrm{LSe}^{\mathrm{acpy}}\right)\right]$ and $\left[\mathrm{Cu}_{2}\left(\mathrm{LSe}^{\mathrm{acpy}}\right)_{3}\right] \mathrm{ClO}_{4}$ were prepared from the reaction of the selenosemicarbazone with $\mathrm{Cu}(\mathrm{OAc})_{2}$ or $\mathrm{Cu}\left(\mathrm{ClO}_{4}\right)_{2}$ in the presence of $\mathrm{Et}_{3} \mathrm{~N}$, respectively. ${ }^{127}$ Both compounds were spectroscopically and structurally characterised. Furthermore, the copper complexes were shown to be involved in the generation of reactive oxygen species and target the lysosome to induce lysosomal membrane permeabilization. ${ }^{127}$ We reported a series of mono- and dinuclear gold(I) phosphine complexes containing derivatives of 2-acetylpyridine selenosemicarbazone. ${ }^{128}$ From X-ray diffraction experiments we could show that these are unique examples of compounds in which the potentially tridentate selenium ligands act as monoanionic Se-ligands towards the gold centre. Some of the compounds display antimalaria activity, although the activity of the corresponding sulfur compounds was higher. ${ }^{128}$

Five-coordinate complexes containing the main group metals $\mathrm{In}^{(\mathrm{III})}, \mathrm{Sb}^{(\mathrm{III})}$ and $\mathrm{Bi}^{(\mathrm{III})}$ including $\left[\mathrm{InBr}_{2}\left(\mathrm{LSe}^{\text {acpy }}\right)\right.$ ], $\left[\mathrm{SbCl}_{2}{ }^{-}\right.$ $\left.\left(\mathrm{LSe}^{\mathrm{acpy}}\right)\right]$ and $\left[\mathrm{BiBr}_{2}\left(\mathrm{LSe}^{\mathrm{acpy}}\right)\right]$ can be prepared from the corresponding metal trihalides and the selenosemicarbazone; the proton being eliminated as HX. ${ }^{129}$ The molecular structures were determined and the thermal behaviour of the indium compound was investigated by DSC/TGA. The complex melts at $262{ }^{\circ} \mathrm{C}$ and starts to lose more than $60 \%$ mass above $500{ }^{\circ} \mathrm{C} .{ }^{129}$ There is thus potential for this type of complex as single-source precursor for InSe materials. Using the same synthetic strategy, we prepared a series of tin(Iv) compounds starting from $\mathrm{SnCl}_{4}$ and the organotin halides $\left[\mathrm{SnCl}_{2} \mathrm{R}_{2}\right]\left(\mathrm{R}=\mathrm{Me},{ }^{n} \mathrm{Bu}, \mathrm{Ph}\right){ }^{130}$ Depending on the tin compound used, different products were obtained and structurally characterised (Fig. 14). Whilst $\mathrm{SnCl}_{4}$ or $\left[\mathrm{SnCl}_{2}\left({ }^{n} \mathrm{Bu}\right)_{2}\right]$ in all cases gave products of the type $\left[\operatorname{SnCl}(\mathrm{R})_{2}\left(\mathrm{LSe}^{\text {acpy }}\right)\right]\left(\mathrm{R}=\mathrm{Cl},{ }^{n} \mathrm{Bu}\right),\left[\mathrm{SnCl}_{2}(\mathrm{Ph})_{2}\right]$ yielded product mixtures containing $\left[\mathrm{SnCl}_{2}(\mathrm{Ph})\left(\mathrm{LSe}^{\text {acpy }}\right)\right]$ and $\left[\mathrm{SnCl}(\mathrm{Ph})_{2}\left(\mathrm{LSe}^{\text {acpy }}\right)\right]$. The former arises from elimination of $\mathrm{PhH}$, whilst in the latter $\mathrm{HCl}$ is liberated during the reaction. Curiously, when using $\left[\mathrm{SnCl}_{2} \mathrm{Me}_{2}\right]$, a salt was isolated containing the five-coordinate $\left[\mathrm{SnMe}_{2}\left(\mathrm{LSe}^{\text {acpy }}\right)\right]^{+}$cation. All of the compounds were characterised by ${ }^{77} \mathrm{Se}$ and ${ }^{119} \mathrm{Sn}$ NMR spectroscopy as well as by ${ }^{119} \mathrm{Sn}$ Mössbauer spectroscopy. ${ }^{130}$

Based on the HSAB-principle, an anionic selenosemicarbazone is classified as a soft base, which would therefore tend to form stable complexes with soft metal ions. The vanadyl cation a)

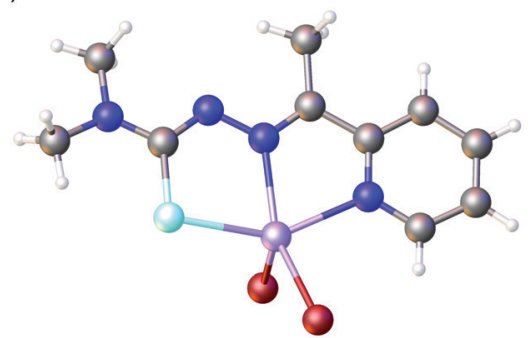

b)

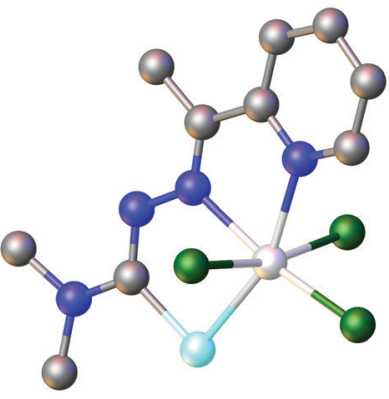

Fig. 14 (a) Molecular structure of $\left[\operatorname{lnBr}_{2}\left(\mathrm{LSe}^{\mathrm{acpy}}\right)\right]$. (b) Molecular structure of [ $\left.\mathrm{SnCl}_{3}\left(\mathrm{LSe}^{\mathrm{acpy}}\right)\right]$. Hydrogen atoms have been omitted for clarity. Atom colours: mint - selenium, blue - nitrogen, grey - carbon, blood red - bromine, lilac - indium, dark green - chlorine, light grey - tin, white - hydrogen. 


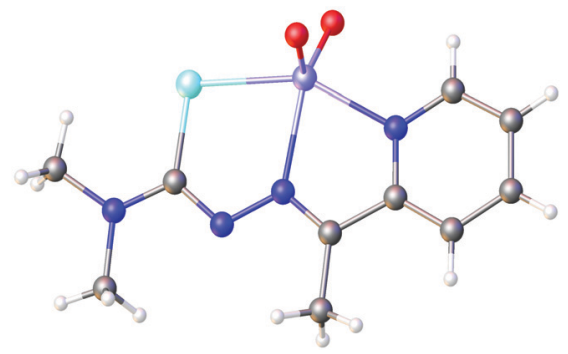

Fig. 15 Molecular structure of $\left[\mathrm{V}(\mathrm{O})_{2}\left(\mathrm{LSe}^{\mathrm{acpy}}\right)\right]$. Atom colours: mint selenium, blue - nitrogen, red - oxygen, grey - carbon, lilac - vanadium, white - hydrogen.<smiles></smiles><smiles>CC1=NN(C#N)[N+]23CC=CC1=C(C)N(C)N=C2[Se]C(N)=N3</smiles>

$\mathrm{M}=\mathrm{Zn}, \mathrm{Cd}$

Fig. 16 Examples of complexes with multidentate selenosemicarbazone ligands.
$[\mathrm{VO}]^{2+}$ is considered a hard metal centre and thus would not be expected to form complexes with soft bases such as a deprotonated selenosemicarbazone. Nevertheless, we could show that 2-acetylpyridine selenosemicarbazone readily reacts with $\left[\mathrm{VO}(\mathrm{acac})_{2}\right]$ to give the green $\mathrm{V}^{(\mathrm{IV})}$ complex $[\mathrm{V}(\mathrm{O})(\mathrm{acac})-$ $\left.\left(\mathrm{LSe}^{\mathrm{acpy}}\right)\right]$, containing both an acac-ligand and the deprotonated $[\mathrm{N}, \mathrm{N}, \mathrm{Se}]^{-}$coordinating selenosemicarbazone. This compound is oxidised in air to the yellow $\mathrm{V}^{(\mathrm{V})}$ dioxo species $\left[\mathrm{V}(\mathrm{O})_{2}\left(\mathrm{LSe}^{\text {acpy }}\right)\right]$ (Fig. 15). ${ }^{131}$ Together with the X-ray structures, we reported the EPR spectrum of the paramagnetic $\mathrm{V}^{(\mathrm{IV})}$ complex.

The reaction of 2-acetylpyridine selenosemicarbazone with $\left[\mathrm{PdCl}_{2}\left(\mathrm{MeCN}_{2}\right]\right.$ or $\mathrm{K}_{2}\left[\mathrm{PtCl}_{4}\right]$ gives the corresponding metal halide complexes $\left[\mathrm{MCl}\left(\mathrm{LSe}^{\mathrm{Py}}\right)\right](\mathrm{M}=\mathrm{Pd}, \mathrm{Pt}) .{ }^{132}$ In the presence of a silver salt and dppe, these complex reacts to afford the phosphine-bridged dinuclear dications $\left[\left(\mathrm{LSe}^{\mathrm{py}}\right) \mathrm{M}(\mu\right.$-dppe $) \mathrm{M}$ $\left.\left(\mathrm{LSe}^{\mathrm{Py}}\right)\right]^{2+}(\mathrm{M}=\mathrm{Pd}, \mathrm{Pt})$, which were isolated as their respective $\mathrm{BPh}_{4}$ salts. In the case of palladium, the same product can be obtained from the selenosemicarbazone and $\left[\operatorname{Pd}(\mathrm{OTf})_{2}(\mathrm{dppe})\right]$ in the presence of base and $\mathrm{NaBPh}_{4} \cdot{ }^{132}$

In a series of papers, the group of Andelkovic reported the preparation, spectroscopic and structural characterisation of metal complexes containing 2-pyridinecarboxaldehyde selenosemicarbazone. These include $\left[\mathrm{CdCl}_{2}\left(\mathrm{HLSe}^{\mathrm{Py}}\right)\right]$ and $\left[\mathrm{ZnCl}_{2}\left(\mathrm{HLSe}^{\mathrm{Py}}\right)\right]$,

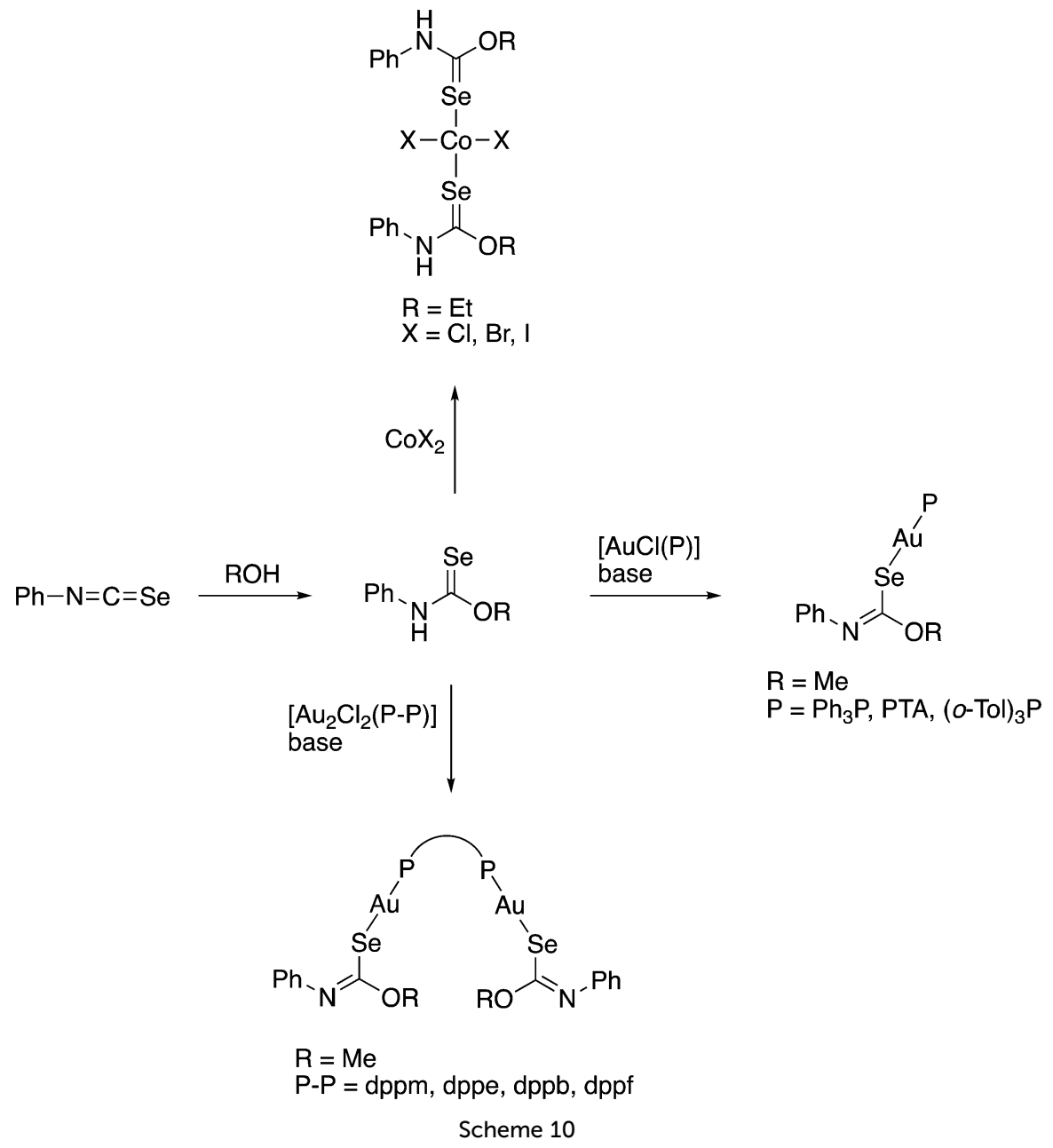


in which the neutral ligand adopts the $[\mathrm{N}, \mathrm{N}, \mathrm{Se}]$ coordination mode. ${ }^{133}$ The square planar $\left[\mathrm{MCl}\left(\mathrm{LSe}^{\mathrm{Py}}\right)\right](\mathrm{M}=\mathrm{Pd}, \mathrm{Pt})$ and octahedral complexes $\left[\mathrm{Co}\left(\mathrm{LSe}^{\mathrm{py}}\right)_{2}\right] \mathrm{BF}_{4}$ and $\left[\mathrm{Ni}\left(\mathrm{LSe}^{\mathrm{py}}\right)_{2}\right]$ were also reported. ${ }^{113}$ In the latter compounds, the selenosemicarbazone is deprotonated and binds to the metal centre via the selenium atom and two nitrogen atoms (pyridyl and imine). Detailed studies of the anticancer activity and the mode of action of these complexes have also been disclosed. ${ }^{113,133-135}$

A potentially pentadentate selenosemicarbazone was prepared by the condensation reaction of 2,6-diacetylpyridine with two equivalents selenosemicarbazide. ${ }^{136}$ Treatment of this bis(selenosemicarbazone) with various metal acetates (Cd, Zn and $\mathrm{Ni}$ ) lead to the isolation of the corresponding complexes, in which the doubly deprotonated selenosemicarbazone is bound to the metal through two selenium- and two imine-nitrogen atoms as well as the nitrogen of the pyridyl group (Fig. 16 left). In the case of the nickel complex, elimination of hydrogen selenide occurs in one of the selenosemicarbazone-arms during complexation, leading to formation of a tetradentate [Se,N,N,N]-selenosemicarbazone (Fig. 16 right). ${ }^{136}$ The in vitro antitumor activity of the bis(selenosemicarbazone) and the three metal complexes were evaluated in several human cancer cell lines. ${ }^{137}$ Whilst the nickel complex was inactive, the bis(selenosemicarbazone) and its $\mathrm{Zn}^{\text {(II) }}$ complex were the most active in all cell lines and were able to induce necrosis.

\subsection{Complexes of selenosemicarbazones containing phosphorus donor atoms}

There is only one reported example of a phosphine-containing selenosemicarbazone. Condensation of 2-(diphenylphosphino)benzaldehyde with selenosemicarbazide affords the corresponding selenosemicarbazone which was subsequently coordinated to a $\mathrm{Ni}^{(\mathrm{II})}$ centre. ${ }^{138}$ In the resulting diamagnetic, square planar complex the ligand acts as a monoanionic $[\mathrm{P}, \mathrm{N}, \mathrm{Se}]^{-}$ligand.

\section{Selenocarbamate esters}

The selenocarbamate ester PhNHC(Se)OEt, obtained from the reaction of $\mathrm{PhNCSe}$ with $\mathrm{EtOH}$, was first reported in 1971 together with a series of $\mathrm{Co}^{(\mathrm{II})}$ complexes in which the compound acts as a neutral Se-donor ligand (Scheme 10). ${ }^{139}$ Our group has reported the preparation and crystal structures of various mono- and dinuclear gold(I) phosphine complexes containing the deprotonated selenocarbamate ester $[\mathrm{PhNC}(\mathrm{Se}) \mathrm{OMe}]^{-}$, which coordinates to gold only via selenium (Scheme 10). ${ }^{140,141}$

\section{Conclusions}

We hoped to illustrate in this article that although the origins of the coordination chemistry of the selenium-containing ligand classes comprising acylselenoureas, selenosemicarbazones and selenocarbamate esters date back more than forty years, there still remains much to explore. The development of modern analytical tools, especially X-ray diffraction and
${ }^{77}$ Se-NMR spectroscopy has allowed researchers to unambiguously elucidate structures of the compounds and to understand their reactivity. A variety of applications including analytical chemistry, materials chemistry (single-source precursors for a range of metal-selenide nanomaterials) as well as medicine (antimicrobial and anticancer activity) will continue to inspire future developments in this area of selenium-coordination chemistry.

\section{Abbreviations}

$\begin{array}{ll}\text { Ac } & \text { acetyl } \\ \text { acac } & \text { acetylacetonate } \\ \text { Bipy } & 2,2^{\prime} \text {-bipyridine } \\ { }^{t} \mathrm{Bu}_{2} \text { Bip } & 4,4^{\prime} \text {-di(tert-butyl)biphenyl-2,2'-diyl } \\ { }^{t} \mathrm{Bu}_{2} \text { bipy } & 4,4^{\prime} \text {-di(tert-butyl)-2,2'-bipyridine } \\ \mathrm{Bz} & \text { benzyl } \\ p \text {-cym } & \text { 1-methyl-4-isopropylbenzene } \\ \text { DMG } & \text { dimethylglyoximato } \\ \text { dppm } & \text { bis(diphenylphosphino)methane } \\ \text { dppe } & \text { 1,2-bis(diphenylphosphino)ethane } \\ \text { dppp } & \text { 1,3-bis(diphenylphosphino)propane } \\ \text { dppb } & \text { 1,4-bis(diphenylphosphino)butane } \\ \text { dppf } & \text { 1,1'-bis(diphenylphosphino)ferrocene } \\ \text { Fc } & \text { ferrocenyl } \\ \text { IPr } & 1,3 \text {-di(2,6-diisopropylphenyl)imidazolylidene } \\ 2 \text {-nap } & \text { 2-naphthyl } \\ \text { OTf } & \text { trifluoromethanesulfonate } \\ \text { Phen } & \text { 1,10-phenanthroline } \\ \text { PTA } & \text { 1,3,5-triaza-7-phosphaadamantane } \\ o \text {-Tol } & \text { 2-methylphenyl } \\ p \text {-Tol } & \text { 4-methylphenyl } \\ \end{array}$

\section{Conflicts of interest}

There are no conflicts to declare.

\section{References}

1 R. A. Hussain, A. Badshah and A. Shah, Appl. Organomet. Chem., 2014, 28, 61-73.

2 L. Beyer, Rev. Colomb. Quim., 1983, 12, 69-85.

3 I. B. Douglass, J. Am. Chem. Soc., 1937, 59, 740-742.

4 Y. Zhou and H. Heimgartner, Helv. Chim. Acta, 2000, 83, 539-553.

5 E. Bulka, K. D. Ahlers and E. Tuček, Chem. Ber., 1967, 100, 1459-1464.

6 E. Bulka, D. Ehlers and E. Storm, Z. Chem., 1970, 10, 403-404.

7 M. Koketsu, Y. Yamamura, H. Aoki and H. Ishihara, Phosphorus, Sulfur Silicon Relat. Elem., 2006, 181, 2699-2708.

8 J. Šibor, D. Žůrek, R. Marek, M. Kutý, O. Humpa, J. Marek and P. Pazdera, Collect. Czech. Chem. Commun., 1999, 64, 1673-1695. 
9 T. B. Wei, H. Wang, Q. Lin and Y. M. Zhang, Chin. J. Org. Chem., 2005, 28, 1565-1569.

10 T. B. Wei, H. Wang, Q. Lin and Y. M. Zhang, Chem. J. Chin. Univ., 2006, 27, 1680-1682.

11 O. López, S. Maza, V. Ulgar, I. Maya and J. G. FernándezBolaños, Tetrahedron, 2009, 65, 2556-2566.

12 Z. J. Witczak, Tetrahedron, 1985, 41, 4781-4785.

13 R. A. Hussain, A. Badshah, M. N. Tahir, B. Lal and I. A. Khan, Aust. J. Chem., 2013, 66, 626-634.

14 R. A. Hussain, A. Badshah, A. Sohail, B. Lal and A. A. Altaf, Inorg. Chim. Acta, 2013, 402, 133-139.

15 R. A. Hussain, A. Badshah, A. Sohail, B. Lal and K. Akbar, J. Mol. Struct., 2013, 1048, 367-374.

16 R. A. Hussain, A. Badshah, M. N. Tahir, T. Ul Hassan and A. Bano, J. Biochem. Mol. Toxicol., 2014, 28, 60-68.

17 R. A. Hussain, A. Badshah, S. Marwat, F. Yasmin and M. N. Tahir, J. Organomet. Chem., 2014, 769, 58-63.

18 R. A. Hussain, A. Badshah, F. Yasmin, M. D. Khan and M. N. Tahir, Aust. J. Chem., 2014, 68, 298-306.

19 R. A. Hussain, A. Badshah, M. D. Khan, N. Haider, B. lal, S. I. Khan and A. Shah, Mater. Chem. Phys., 2015, 159, 152-158.

20 J. C. Bruce, N. Revaprasadu and K. R. Koch, New J. Chem., 2007, 31, 1647-1653.

21 J. C. Bruce and K. R. Koch, Acta Crystallogr., Sect. C: Cryst. Struct. Commun., 2008, C64, m1-m4.

22 M. Schuster and K. H. König, Fresenius Z. Anal. Chem., 1987, 327, 102-104.

23 R. Herzschuh, B. Birner, L. Beyer, F. Dietze and E. Hoyer, Z. Anorg. Allg. Chem., 1980, 464, 159-168.

24 A. Molter, J. Rust, C. W. Lehmann and F. Mohr, ARKIVOC, 2011, vi, 10-17.

25 M. Kampf, R. Richter, J. Griebel, A. Weller and R. Kirmse, Z. Anorg. Allg. Chem., 2005, 631, 698-708.

26 M. Kampf, R. Richter, L. Hennig, A. Eidner, J. Baldamus and R. Kirmse, Z. Anorg. Allg. Chem., 2004, 630, 2677-2686.

27 J. Akhtar, M. A. Malik, S. K. Stubbs, P. O’Brien, M. Helliwell and D. J. Binks, Eur. J. Inorg. Chem., 2011, 2984-2990.

28 J. Akhtar, R. F. Mehmood, M. A. Malik, N. Iqbal, P. O’Brien and J. Raftery, Chem. Commun., 2011, 47, 1899-1901.

29 A. Molter, S. Kathrein, B. Kircher and F. Mohr, Dalton Trans., 2018, 47, 5055-5064.

30 K. Klauke, A. Schmitz, A. C. Swertz, B. B. Beele, B. Geisen, C. Schlüsener, C. Janiak and F. Mohr, New J. Chem., 2020, 44, 7719-7726.

31 M. Perez Rodriguez, M. Cubero and A. Lopez Castro, Nature, 1963, 200, 1091.

32 H. Hope, Acta Crystallogr., 1965, 18, 259-264.

33 L. Beyer, R. Kirmse and E. Hoyer, Z. Chem., 1975, 15, 197.

34 R. Kirmse, L. Beyer and E. Hoyer, Chem. Phys. Lett., 1977, 49, 544-546.

35 R. Kirmse, L. Beyer and E. Hoyer, Z. Chem., 1975, 15, 454-455.

36 J. Stach, R. Kirmse, A. Heinrich, W. Dietzsch, J. Hartung and L. Beyer, Z. Chem., 1983, 23, 453-454.

37 M. Kampf, R. Richter, L. Hennig, A. Eidner, J. Baldamus and R. Kirmse, Z. Anorg. Allg. Chem., 2004, 630, 2677-2686.
38 M. Kampf, R. Richter, J. Griebel, A. Weller and R. Kirmse, Z. Anorg. Allg. Chem., 2005, 631, 698-708.

39 A. Rodenstein, J. Griebel, R. Richter and R. Kirmse, $Z$. Anorg. Allg. Chem., 2008, 634, 1735-1741.

40 Y. Salyn, E. K. Zhumandilov, V. I. Nefedov, R. Scheibe, G. Leonhardt, L. Beyer and E. Hoyer, Z. Anorg. Allg. Chem., 1977, 432, 275-279.

41 V. I. Nefedov and E. K. Zhumandilov, Inorg. Chim. Acta, 1978, 30, L285-L286.

42 E. Kleinpeter and L. Beyer, J. Prakt. Chem., 1975, 317, 938-942.

43 L. Beyer, S. Behrendt, E. Kleinpeter, R. Borsdorf and E. Hoyer, Z. Anorg. Allg. Chem., 1977, 437, 282-288.

44 E. Kleinpeter, S. Behrendt and L. Beyer, Z. Anorg. Allg. Chem., 1982, 495, 105-114.

45 R. Herzschuh, B. Birner, L. Beyer, F. Dietze and E. Hoyer, $Z$. Anorg. Allg. Chem., 1980, 464, 159-168.

46 J. Stach, R. Herzschuh, R. Kirmse, L. Beyer and J. Hartung, Z. Anorg. Allg. Chem., 1984, 514, 223-230.

47 K. H. König, H. J. Pletsch and M. Schuster, Fresenius Z. Anal. Chem., 1986, 325, 621-624.

48 M. Schuster and K. H. König, Fresenius Z. Anal. Chem., 1988, 331, 383-386.

49 D. P. Bendito, J. Casillas and F. Pino, Inf. Quim. Anal., 1966, 20, 69-75.

50 D. P. Bendito and F. Pino, Inf. Quim. Anal., 1967, 21, 9-13.

51 F. Pino-Pérez, F. Burriel Matí and J. M. Balcells, An. R. Soc. Esp. Fis. Quim., Ser. B, 1959, 55B, 579-590.

52 S. C. Shome, M. Mazumdar and S. K. Das, J. Ind. Chem. Soc., 1980, 57, 69-72.

53 J. Akhtar, J. C. Bruce, M. A. Malik, K. R. Koch, M. Afzaal and P. O'Brien, Mater. Res. Soc. Symp. Proc., 2009, 1148E, 1148PP1112-1108.

54 J. Akhtar, M. Akhtar, M. A. Malik, P. O’Brien and J. Raftery, J. Am. Chem. Soc., 2012, 134, 2485-2487.

55 S. A. Saah, P. D. McNaughter, M. A. Malik, J. A. M. Awudza, N. Revaprasadu and P. O'Brien, J. Mater. Sci., 2018, 53, 4283-4293.

56 T. E. Ezenwa, P. D. McNaughter, J. Raftery, D. J. Lewis and P. O’Brien, Dalton Trans., 2018, 47, 16938-16943.

57 S. A. Saah, M. D. Khan, P. D. McNaughter, J. A. M. Awudza, N. Revaprasadu and P. O'Brien, New J. Chem., 2018, 42, 16602-16607.

58 M. Akhtar, J. Akhtar, M. A. Malik, F. Tuna, M. Helliwell and P. O'Brien, J. Mater. Chem., 2012, 22, 14970-14975.

59 K. Rosenbaum, L. Beyer, R. Richter and E. Hoyer, Z. Anorg. Allg. Chem., 1992, 617, 89-92.

60 G. Weber, J. Hartung and L. Beyer, Tetrahedron Lett., 1988, 29, 3475-3476.

61 Y. Zhou, A. Linden and H. Heimgartner, Helv. Chim. Acta, 2000, 83, 1576-1598.

62 A. Bredenkamp, X. Zeng and F. Mohr, Polyhedron, 2012, 33, 107-113.

63 R. Köhler, L. Beyer, R. Richter, J. Sieler and J. Stach, Z. Anorg. Allg. Chem., 1991, 600, 73-81.

64 A. Rodenstein, J. A. Odendal, R. Kirmse and K. R. Koch, Inorg. Chem. Commun., 2011, 14, 99-102. 
65 W. Bensch and M. Schuster, Z. Anorg. Allg. Chem., 1993, 619, 1689-1692.

66 M. Schuster and W. Bensch, Z. Anorg. Allg. Chem., 1994, 620, 737-742.

67 M. Schuster and W. Bensch, Z. Naturforsch., B: J. Chem. Sci., 1994, 49b, 1615-1619.

68 W. Bensch and M. Schuster, Z. Anorg. Allg. Chem., 1993, 619, 791-795.

69 W. Bensch and M. Schuster, Z. Anorg. Allg. Chem., 1993, 619, 786-790.

70 W. Bensch and M. Schuster, Z. Anorg. Allg. Chem., 1994, 620, 177-182.

71 W. Bensch and M. Schuster, Z. Anorg. Allg. Chem., 1994, 620, 1479-1482.

72 A. Molter and F. Mohr, Z. Naturforsch., B: J. Chem. Sci., 2013, 68, 91-94.

73 A. Molter, J. Rust, C. W. Lehmann and F. Mohr, Tetrahedron, 2012, 68, 10586-10591.

74 J. Kuchar, J. Rust, C. W. Lehmann and F. Mohr, New J. Chem., 2019, 10750-10754.

75 F. Fuge, C. Lehmann and F. Mohr, J. Organomet. Chem., 2009, 694, 2395-2401.

76 A. Molter, J. Rust, C. W. Lehmann and F. Mohr, Inorg. Chem. Commun., 2016, 73, 69-71.

77 B. David, U. Monkowius, J. Rust, C. W. Lehmann, L. Hyzak and F. Mohr, Dalton Trans., 2014, 43, 11059-11066.

78 A. Molter, PhD thesis, University of Wuppertal, 2011.

79 V. D. Schwade, A. Hagenbach, E. Shulz Lang, K. Klauke, F. Mohr and U. Abram, Eur. J. Inorg. Chem., 2014, 1949-1954.

80 M. Dörner, J. M. Rautiainen, J. Rust, C. W. Lehmann and F. Mohr, Eur. J. Inorg. Chem., 2017, 789-797.

81 J. Kuchar, J. Rust, C. W. Lehmann and F. Mohr, Eur. J. Inorg. Chem., 2018, 5215-5222.

82 R. Huls and M. Renson, Bull. Soc. Chim. Belg., 1956, 65, 511-522.

83 R. Huls and M. Renson, Bull. Soc. Chim. Belg., 1956, 65, 684-695.

84 J. M. Cano Pavon and F. Pino, Talanta, 1972, 19, 1659-1663.

85 D. J. Fry and P. J. Keogh, UK Pat., GB1326597, 1973.

86 P. Bippus, A. Molter, D. Müller and F. Mohr, J. Organomet. Chem., 2010, 695, 1657-1662.

87 A. V. Ablov, N. V. Gerbeleu and A. M. Romanov, Russ. J. Inorg. Chem., 1968, 13, 413-416.

88 A. V. Ablov, N. V. Gerbeleu, A. M. Romanov and V. M. Vlad, Russ. J. Inorg. Chem., 1971, 16, 718-719.

89 A. N. Vedyanu and N. V. Gerbeleu, Russ. J. Inorg. Chem., 1976, 21, 1828-1831.

90 D. Negoiu and I. Ghelase, Rev. Roum. Chim., 1983, 28, 225-234.

91 D. Negoiu and I. Ghelase, Rev. Roum. Chim., 1983, 28, 355-364.

92 I. Ghelase and D. Negoiu, Rev. Roum. Chim., 1983, 28, 463-470.

93 A. V. Ablov, N. V. Gerbeleu and A. M. Romanov, Russ. J. Inorg. Chem., 1968, 13, 1558-1561.
94 N. V. Gerbeleu, M. D. Revenko and A. V. Ablov, Russ. J. Inorg. Chem., 1972, 17, 709-710.

95 N. V. Gerbeleu, M. D. Revenko and A. V. Ablov, Russ. J. Inorg. Chem., 1972, 17, 71-74.

96 N. V. Gerbeleu and M. D. Revenko, Russ. J. Inorg. Chem., 1972, 17, 1132-1135.

97 Unfortunately, the structure is of poor quality, however the atom connectivity can be unambiguously established.

98 T. N. Tarkhova, L. E. Nikolaeva, M. A. Simonov, A. V. Ablov, N. V. Gerbeleu and A. M. Romanov, Dokl. Chem., 1974, 214, 138-141.

99 L. E. Nikolaeva, A. A. Shevyrev, T. N. Tarkhova and N. V. Belov, Sov. Phys. Crystallogr., 1974, 19, 320-322.

100 N. V. Gerbeleu and V. G. Bodyu, Russ. J. Inorg. Chem., 1972, 17, 857-859.

101 V. G. Bodyu and N. V. Gerbeleu, Russ. J. Inorg. Chem., 1972, 17, 1123-1125.

102 N. Y. Negryatse, A. V. Ablov and N. V. Gerbeleu, Russ. J. Inorg. Chem., 1972, 17, 65-67.

103 N. V. Gerbeleu and V. G. Bodyu, Russ. J. Inorg. Chem., 1973, 18, 1596-1598.

104 A. V. Ablov, N. V. Gerbeleu and N. Y. Negryatse, Russ. J. Inorg. Chem., 1969, 14, 515-517.

105 A. V. Ablov, N. V. Gerbeleu and N. Y. Negryatse, Russ. J. Inorg. Chem., 1970, 15, 61-62.

106 A. V. Ablov, N. V. Gerbeleu and N. Y. Negryatse, Russ. J. Inorg. Chem., 1971, 16, 568-571.

107 V. Y. Plotkin, M. G. Felin, N. A. Subbotina and V. V. Zelentsov, Russ. J. Inorg. Chem., 1983, 28, 825-827.

108 A. V. Ablov, N. V. Gerbeleu and B. T. Oloi, Russ. J. Inorg. Chem., 1971, 16, 379-382.

109 B. T. Oloi, N. V. Gerbeleu and A. V. Ablov, Russ. J. Inorg. Chem., 1971, 16, 1537-1538.

110 M. D. Revenko, V. I. Prisacari, A. V. Dizdari, E. F. Stratulat, I. D. Corja and L. M. Proca, Pharm. Chem. J., 2011, 45, 351-354.

111 N. R. Filipović, S. Bjelogrlić, G. Portalone, S. Pelliccia, R. Silvestri, O. Klisurić, M. Senćanski, D. Stanković, T. R. Todorović and C. D. Muller, MedChemComm, 2016, 7, 1604-1616.

112 N. Gligorijević, T. R. Todorović, S. Radulović, D. M. Sladić, N. R. Filipović, D. Godevac, D. Jeremić and K. K. Andelković, Eur. J. Med. Chem., 2009, 44, 1623-1629.

113 T. R. Todorović, A. Bacchi, D. M. Sladić, N. M. Todorović, T. T. Božić, D. D. Radanović, N. R. Filipović, G. Pelizzi and K. K. Anđelković, Inorg. Chim. Acta, 2009, 362, 3813-3820.

114 N. Filipović, N. Polović, B. Rašković, S. Misirlić-Denčić, M. Dulović, M. Savić, M. Nikšić, D. Mitić, K. Andelković and T. Todorović, Monatsh. Chem., 2014, 145, 1089-1099.

115 N. R. Filipović, S. Bjelogrlić, A. Marinković, T. Ž. Verbić, I. N. Cvijetić, M. Senćanski, M. Rodić, M. Vujěić, D. Sladić, Z. Striković, T. R. Todorović and C. D. Muller, RSC Adv., 2015, 5, 95191-95211.

116 I. S. Đordevic, J. Vukašinović, T. R. Todorović, N. R. Filipović, M. V. Rodić, A. Lolić, G. Portalone, M. Zlatović and S. Grubišić, J. Serb. Chem. Soc., 2017, 82, 825-839. 
117 C. Pizzo, P. Faral-Tello, G. Salina, M. Fló, C. Robello, P. Wipf and G. Mahler, Med. Chem. Commun., 2012, 3, 362-368.

118 C. Pizzo, P. Faral-Tello, G. Yaluff, E. Serna, S. Torres, N. Vera, C. Saiz, C. Robello and G. Mahler, Eur. J. Med. Chem., 2016, 109, 107-113.

119 J. P. Scovill, D. L. Klayman and C. F. Franchino, US Pat., US4657903, 1987.

120 Y. K. Bhoon, J. P. Scovill and D. L. Klayman, Indian J. Chem., 1983, 22A, 267-269.

121 D. L. Klayman, J. P. Scovill, J. F. Bartosevich and C. J. Mason, Eur. J. Med. Chem., 1981, 16, 317-320.

122 D. X. West, P. M. Ahrweiler, G. Ertem, J. P. Scovill, D. L. Klayman, J. L. Flippen-Anderson, R. Gilardi, C. George and L. K. Pannell, Transition Met. Chem., 1985, 10, 264-270.

123 D. X. West, J. P. Scovill, J. V. Silverton and A. Bavoso, Transition Met. Chem., 1986, 11, 123-131.

124 B. S. Garg, M. R. P. Kurup, S. K. Jain and Y. K. Bhoon, Transition Met. Chem., 1988, 13, 92-95.

125 C. R. Kowol, R. Eichinger, M. A. Jakupec, M. Galanski, V. B. Arion and B. K. Keppler, J. Inorg. Biochem., 2007, 101, 1946-1957.

126 C. R. Kowol, E. Reisner, I. Chiorescu, V. B. Arion, M. Galanski, D. V. Deubel and B. K. Keppler, Inorg. Chem., 2008, 47, 11032-11047.

127 Z. Al-Eisawi, C. Stefani, P. J. Jansson, A. Arvind, P. C. Sharpe, M. T. Basha, G. M. Iskander, N. Kumar, Z. Kovacevic, D. J. R. Lane, S. Sahni, P. V. Bernhardt, D. R. Richardson and D. S. Kalinowski, J. Med. Chem., 2016, 59, 294-312.
128 A. Molter, J. Rust, C. W. Lehmann, G. Deepa, P. Chiba and F. Mohr, Dalton Trans., 2011, 40, 9810-9820.

129 A. Molter and F. Mohr, Dalton Trans., 2011, 40, 3754-3758.

130 A. Molter, G. N. Kaluderovic, H. Kommera, R. Paschke, T. Langer, R. Poettgen and F. Mohr, J. Organomet. Chem., 2012, 701, 80-86.

131 A. Molter, E. Bill and F. Mohr, Inorg. Chem. Commun., 2012, 17, 124-127.

132 A. Molter and F. Mohr, Polyhedron, 2016, 120, 118-123.

133 S. Bjelogrlić, T. Todorović, A. Bacchi, M. Zec, D. Sladić, T. Srdić-Rajić, D. Radanović, S. Radulović, G. Pelizzi and K. Andelković, J. Inorg. Biochem., 2010, 104, 673-682.

134 T. Srdić-Rajić, M. Zec, T. Todorović, K. Andelković and S. Radulović, Eur. J. Med. Chem., 2011, 46, 3734-3747.

135 M. Zec, T. Srdic-Rajic, A. Konic-Ristic, T. Todorovic, K. Andjelkovic, I. Filipovic-Ljeskovic and S. Radulovic, Anti-Cancer Agents Med. Chem., 2012, 12, 1071-1080.

136 T. R. Todorović, A. Bacchi, G. Pelizzi, N. O. Juranić, D. M. Sladić, I. D. Brčeski and K. K. Andelkovića, Inorg. Chem. Commun., 2006, 9, 862-865.

137 M. Zec, T. Srdic-Rajic, A. Krivukuca, R. Jankovic, T. Todorović, K. Andelkovic and S. Radulovic, Med. Chem., 2014, 10, 759-771.

138 I. D. Brčeski, V. M. Leovac, G. A. Bogdanović, S. P. Sovilj and M. Revenco, Inorg. Chem. Commun., 2004, 7, 253-256.

139 P. Porta, T. Tarantelli, L. Gastaldi and C. Furlani, Inorg. Chim. Acta, 1971, 5, 616-622.

140 D. Gallenkamp, E. Tiekink and F. Mohr, Phosphorus, Sulfur Silicon Relat. Elem., 2008, 183, 1050-1056.

141 D. Gallenkamp, T. Porsch, A. Molter, E. R. T. Tiekink and F. Mohr, J. Organomet. Chem., 2009, 694, 2380-2385. 